\title{
GREATER-THAN-CLASS-C LOW-LEVEL WASTII DATA BASE USER'S MANUAL
}

August 1992

\author{
Idaho National Engineering Laboratory \\ EG\&G Idaho, Inc. \\ National Low-Level Waste Management Program \\ P.O. Box 1625 \\ Idaho Falls, ID 83415
}

\section{DISCLAIMER}

This report was prepared as an account of work sponsored by an agency of the United States Government. Neither the United States Government nor any agency thereof, nor any of their employees, makes any warranty, express or implied, or assumes any legal liability or responsibility for the accuracy, completeness, or usefulness of any information, apparatus, product, or process disclosed, or represents that its use would not infringe privately uwned rights. Reference herein to any specific commercial product, process, or service by trade namc, trademaik, manufacturer, or otherwise does not necessarily constitute or imply its endorsement, recommendation, or favoring by the United States Government or any agency thereof. The views and opinions of authors expressed herein do not necessarily state or reflect those of the United States Government or any agency thereof.

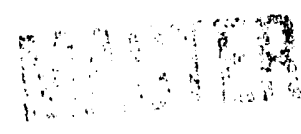




\section{Greater-than-Class-C Low-Level Waste Data Base User's Manual}

August 1992


Mary T. Magleby

Date
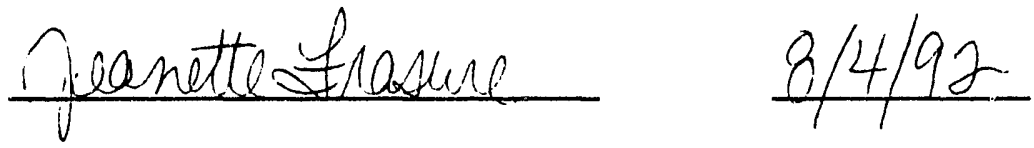

Jeanette Frasure

Date

E\&WMC Technical Coordinator 


\section{ABSTRACT}

The Greater-than-Class-C Low-Level Waste (GTCC LLW) Data Base characterizes GTCC LLW using low, base, and high cases for three different scenarios: unpackaged, packaged, and concentration averages. The GTCC LLW Data Base can be used to project future volumes and radionuclide activities. This manual provides instructions for users of the GTCC LLW Data Base. 


\section{CONTENTS}

1. Introduction $\ldots \ldots \ldots \ldots \ldots \ldots \ldots \ldots \ldots \ldots \ldots$

2. Getting Started $\ldots \ldots \ldots \ldots \ldots \ldots \ldots \ldots \ldots \ldots \ldots \ldots$

System Requirements .................. 3

Setting Up GTCC LLW System ............. 4

3. Function Keys $\ldots \ldots \ldots \ldots \ldots \ldots \ldots \ldots \ldots \ldots$

4. Logging On and Off $\ldots \ldots \ldots \ldots \ldots \ldots \ldots \ldots \ldots$

Logging On $\ldots \ldots \ldots \ldots \ldots \ldots \ldots \ldots \ldots \ldots$

Logging Off $\ldots \ldots \ldots \ldots \ldots \ldots \ldots \ldots \ldots \ldots$

5. Select or Copy A Scenario . . . . . . . . . . . . 17

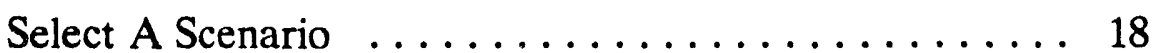

Copy a Scenario $\ldots \ldots \ldots \ldots \ldots \ldots \ldots \ldots \ldots 22$

6. Edit Scenario $\ldots \ldots \ldots \ldots \ldots \ldots \ldots \ldots \ldots \ldots \ldots \ldots \ldots$

Waste Stream Volumes $\ldots \ldots \ldots \ldots \ldots \ldots \ldots . \ldots 28$

Edit Concentrations $\ldots \ldots \ldots \ldots \ldots \ldots \ldots \ldots \ldots$

Plant Information (Reactors) $\ldots \ldots \ldots \ldots \ldots \ldots, 32$

Scenario Data..$\ldots \ldots \ldots \ldots \ldots \ldots \ldots$.

Plant Component Exposure . . . . . . . . . . . . 37

Sealed Source Information ................ 39 
Package Factors $\ldots \ldots \ldots \ldots \ldots \ldots \ldots \ldots$

Concentration Average Factors $\ldots \ldots \ldots \ldots \ldots$. . . 4

Project on This Scenario $\ldots \ldots \ldots \ldots \ldots$

7. Project on Scenario .................. 47

8. Report on Projections .................. 49

9. Query Projections to Screen $\ldots \ldots \ldots \ldots \ldots$

10. Delete Scenario . . . . . . . . . . . . . 57

11. Master User Edit . . . . . . . . . . . . . . . . 59

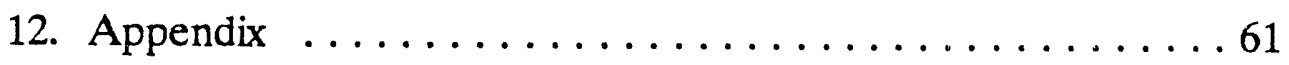


1. Help screen $\ldots \ldots \ldots \ldots \ldots \ldots \ldots \ldots \ldots \ldots \ldots$

2. GTCC LI.W Data Base - Main Menu ... . . . . . . . 14

3. Select or copy a scenario menu $\ldots \ldots \ldots \ldots \ldots \ldots \ldots 17$

4. Select a scenario menu $\ldots \ldots \ldots \ldots \ldots \ldots \ldots \ldots . \ldots \ldots$

5. Display scenario menu $\ldots \ldots \ldots \ldots \ldots \ldots \ldots \ldots$

6. Continue editing scenario screen $\ldots \ldots \ldots \ldots \ldots \ldots \ldots$

7. Continue projecting on scenario screen $\ldots \ldots \ldots \ldots \ldots 21$

8. Get new name screen $\ldots \ldots \ldots \ldots \ldots \ldots \ldots \ldots 22$

9. List of scenario names $\ldots \ldots \ldots \ldots \ldots \ldots \ldots \ldots \ldots$

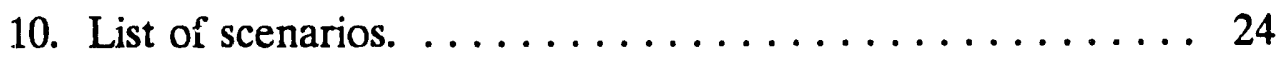

11. Copy scenario screen $\ldots \ldots \ldots \ldots \ldots \ldots \ldots \ldots \ldots \ldots$

12. Edit scenario menu screen $\ldots \ldots \ldots \ldots \ldots \ldots \ldots \ldots 27$

13. Edit waste stream screen $\ldots \ldots \ldots \ldots \ldots \ldots \ldots \ldots 28$

14. Edit concentration screen $\ldots \ldots \ldots \ldots \ldots \ldots \ldots .30$

15. Edit reactor screen $\ldots \ldots \ldots \ldots \ldots \ldots \ldots \ldots \ldots \ldots \ldots \ldots \ldots$

16. Edit scenario screen $\ldots \ldots \ldots \ldots \ldots \ldots \ldots \ldots \ldots \ldots$

17. Plant component exposure screen $\ldots \ldots \ldots \ldots \ldots \ldots 37$

18. Sealed source information screen $\ldots \ldots \ldots \ldots \ldots \ldots \ldots 39$ 
19. Package factor screen $\ldots \ldots \ldots \ldots \ldots \ldots \ldots$

20. Concentration average factors $\ldots \ldots \ldots \ldots \ldots$

21. Project on scenario screen $\ldots \ldots \ldots \ldots \ldots \ldots$

22. Run calculations screen $\ldots \ldots \ldots \ldots \ldots \ldots \ldots$

23. Report on projections screen ................ 49

24. Get report screen $\ldots \ldots \ldots \ldots \ldots \ldots \ldots$

25. GTCC LLW characterization report screen $\ldots \ldots \ldots \ldots 1$

26. Query projections to screen $\ldots \ldots \ldots \ldots \ldots 5$

27. Volume results screen $\ldots \ldots \ldots \ldots \ldots \ldots$

28. Delete scenario screen . . . . . . . . . . . . . 57 


\section{TABLES}

1. Function key descriptions for GTCC LLW Data Base $\ldots \ldots 6$

2. Reactor reference table $\ldots \ldots \ldots \ldots \ldots \ldots \ldots \ldots, 33$ 


\section{Introduction}

The Greater-than-Class-C Low-Level Waste (GTCC LLW) Data Base was designed to characterize GTCC LLW using low, base, and high cases for three different scenarios: unpackaged, packaged, and concentration averages. This manual helps you use the GTCC LLW Data Base to project future volumes and radionuclide activities. 
Section 1

Introduction 


\section{Getting Started}

\section{System Requirements}

Running the GTCC LLW Data Base requires the following:

- A PC with a minimum of $640 \mathrm{~K}$ bytes of randomaccess memory

- A hard-disk drive with a minimum of 1 megabyte of free disk space to accommodate report files for printing

- A floppy-disk drive for off-loading or copying the GTCC LLW system reports

- A printer

- TCP/IP Communication Software (either 3Com or Excelan). 


\section{Setting Up GTCC LLW System}

This section explains how the GTCC LLW Data Base is installed onto your PC.

The TCP/IP (either 3Com or Excelan) software must be installed and running on your PC before attempting to execute the GTCC LLW system.

1. The server system administrator and data base administrator will set up the necessary files on the server to execute the GTCC LLW system.

2. The system administrator will create an account for the user on the data base server.

3. The data base administrator will add the user to the Oracle system and grant the user access to the appropriate tables.

4. The system administrator will place a file in the user's home directory (/u/users/ $\mathrm{xxx}$ where $\mathrm{xxx}$ indicates the userid) to execute the GTCC LLW system (gtccstart). This script file may be executed automatically upon login (after entering the userid and password), or the user may execute it manually by typing gtccstart. The gtccstart file contains commands to change to the GTCC LLW project directory and execute the main menu screen. Upon completion of the system, the user will be back in their home directory. 


\section{Function Keys}

The function key system was designed to make the GTCC LLW system easy to use. Throughout this manual, the function keys are referred to by their assigned names (e.g., List of values).

Important function key names will be displayed at the bottom of the screen when you are using the GTCC LLW Data Base.

The function keys may differ with different keyboard maps. To display the list of function keys for your keyboard, press Help $(<F 1>$ ) for the function keys screen. (Note: if the $<F 1>$ key is not programmed for your key map, try typing $<\mathrm{Ctrl}>-\mathrm{K}$ or $<\mathrm{Esc}>-\mathrm{K}$.) Figure 1 presents an example help screen.

\begin{tabular}{|c|c|c|c|}
\hline FUNCTION & $\operatorname{KEYSTROKE}(S)$ & FUNCTION' & KEYSTROKE (S) \\
\hline $\begin{array}{l}\text { Right } \\
\text { Next Field } \\
\text { Next Primary Key Fld } \\
\text { Next Record } \\
\text { Next Block } \\
\text { Left } \\
\text { Previous Field } \\
\text { Previous Record } \\
\text { Previous Block } \\
\text { Insert/Replace } \\
\text { Delete Backward } \\
\text { Clear Field } \\
\text { Clear Recora } \\
\text { Clear Block } \\
\text { Clear Form/Rollback } \\
\text { De lete Record } \\
\text { Create Record } \\
\text { Duplicate Field } \\
\text { Duplicate Record }\end{array}$ & $\begin{array}{l}-> \\
\text { TAB } \\
\text { RETURN } \\
\text { OK } \\
\text { Down Arrow } \\
\text { "F } \\
\angle- \\
\text {-B } \\
\text { Up Arrow } \\
\text { Escape B } \\
\text { Insert } \\
\text { Backspace } \\
\text { OV } \\
\text { OW } \\
\text { OY } \\
\text {-U } \\
\text { OD } \\
\text { N } \\
\text { Escape } 0 \\
\text { Escape C }\end{array}$ & $\begin{array}{l}\text { Enter Query } \\
\text { Count Query Hits } \\
\text { Execute Query } \\
\text { Comnit Transaction } \\
\text { Exit/Cancel } \\
\text { Print } \\
\text { Redisplay Page } \\
\text { Help } \\
\text { Display Error } \\
\text { Block Menu } \\
\text { Show Function Keys }\end{array}$ & 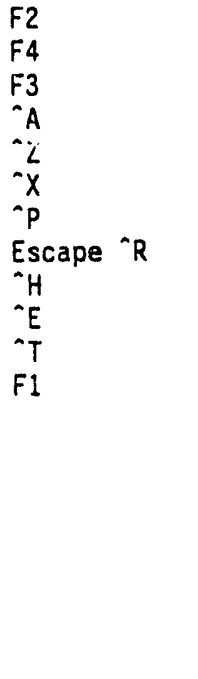 \\
\hline
\end{tabular}

Figure 1. Help screen. 
The following list defines the function key names in alphabetical order.

Table 1. Function key descriptions for GTCC LLW Data Base.

Field Title

Block menu

Clear block

Clear field

\section{Description}

Displays a list of all the blocks in the current form. From this list, you can select the block to which you would like to move.

When you choose a block from the block menu, the cursor moves to that block. If a form has many blocks, Block menu will usually move the cursor to a block more quickly than Next block or Previous block.

Clears work space to allow new record input. Clear block might prompt you to commit your changes.

Clear block does not deleted records from the data base; it only removes records from the work space.

Clears the contents of the current field beginning at the current cursor position. If the cursor is to the right of all the characters in the field, Clear field clears to the end of the line. 
Table 1. (continued).

Field Title

Clear form/rollback

Clear secord

Commit transaction

Create record

Count query hits
Description

Clears all the blocks of the current form, deletes all data in all blocks of the form, and does a rollback

Clear form/rollback undoes all inserts, updates, and deletes posted to the data base but does not delete records from the data base; it only removes records from the work space.

Removes the current record from the current block, reversing any uncommitted changes made to that record. A cleared record is NOT deleted from the data base.

Saves to the data base the data entered on the form.

Creates a new record after the current record. Use with Duplicate record.

Clears the current block and displays on the message line the number of rows that a query would retrieve if executed. If you are in enter query mode, the current block does not clear.

When used in enter query mode, Count query hits counts the number of records matching the specified search criteria. 
Table 1. (continued).

\begin{tabular}{|c|c|}
\hline Field Title & Description \\
\hline & $\begin{array}{l}\text { Note: If you press Count query hits } \\
\text { after pressing Execute query, it } \\
\text { terminates the query, clears all the } \\
\text { records from the work space, and counts } \\
\text { all of the records in the table that can be } \\
\text { retrieved by the block. }\end{array}$ \\
\hline
\end{tabular}

Delete backward

Deletes the character to the left of the current cursor position.

Delete record

Deletes a retrieved record from the screen and from the data base. Records are not permanently deleted until you commit your changes to the data base.

Display error

Displays error information and/or advanced help information, if available, for the field where the last error occurred.

Duplicate field

Copies the field value from the same field of the previous record into the current field.

Duplicate record

Copies all field values from the previous record into a new record.

Enter query

Clears the current block and allows you enter query criteria. Use $\%$ to query similar values (e.g., $\mathrm{ABC} \%$ returns 
Table 1. (continued).

\section{Field Title}

\section{Description}

everything beginning with $A B C$ ). In enter query mode, the following keys have these functions:

- Enter query displays the query criteria last used.

- Execute query performs the query. If records are retrieved, returns to normal operation; however, if no records are found, remains in enter query mode.

- Exit/cancel returns to normal operation without performing the query.

- Count query hits displays the number of rows that satisfy the query.

Execute query

Exit/cancel 
Table 1. (continued).

Field Title

Help

Insert/replace

Left

I ist of values

Next block

Next field

Next primary key fld

\section{Description}

clears that screen and returns you to the GTCC LLW Data Base Main Menu. Pressing Exit/cancel from the Main Menu causes you to exit the GTCC LLW system.

Displays the help screen for the current field or form, if available.

Toggles between insert and replace character modes for text entry.

Moves the cursor one character to the left.

Lists all of the information in the current block.

Moves the cursor to the next block in the form that contains at least one enterable field.

Moves the cursor to the next enterable field.

Moves the cursor to the next enterable field in the current record that has been designated as part of the "primary key" - those fields that uniquely identify a particular row of a data base table. 
Table 1. (continued).

Field Title

Next record

Previous block

Previous field

Previous record

Print

Redisplay page

Right

\section{Description}

Moves the cursor to the next record in the current block. If no more records ar found, Next record creates a new blank record (unless the current record is blank).

Moves the cursor to the previous block in the form that contains at least one enterable field.

Moves the cursor to the previous enterable field.

Moves the cursor to the previous record the current block.

Writes the current screen to a file and asks if you want to print it.

Refreshes the screen.

Moves the cursor one character to the right (within a field or a line). 
Section 3

Function Keys 


\section{Logging On and Off}

\section{Logging On}

Before attempting to log or, ensure that the GTCC LLW Data Base is properly installed. Refer to Section 2, Getting Started.

The following describes logging onto the GTCC LLW Data Base.

1. At the screen prompt $\mathbf{C :} \mid>$ :

- If you are using IBM models 70,80 , or 90 , type ed c: $\mid 3 c 523$ and press <ENTER> (this changes the directory). To execute the GTCC LLW system, type $3 c 523$ and press <ENTER>.

- If you are using an IBM AT, XT, Compaq, or other Industry Standard Architecture (ISA) or Extended Industry Standard Architecture (EISA) machine, type cd c: $\mid 3 c 501$ and press <ENTER> (this changes the directory). To execute the GTCC LLW system, type 36500 and press <ENTER>.

The prompt $\mathbf{C :} \mid>$ should appear again after the TCP/IP software has been started.

2. Type tnvt boink1 and press <ENTER $>$.

3. At login:, type in your userid and press <ENTER $>$.

4. At password:, type in your password and press <ENTER>. The prompt /u/users/userid $>$ should appear. 
5. Type gtccstart and press <ENTER>.

6. The GTCC LLW main menu will appear on the screen, similar to Figure 2.

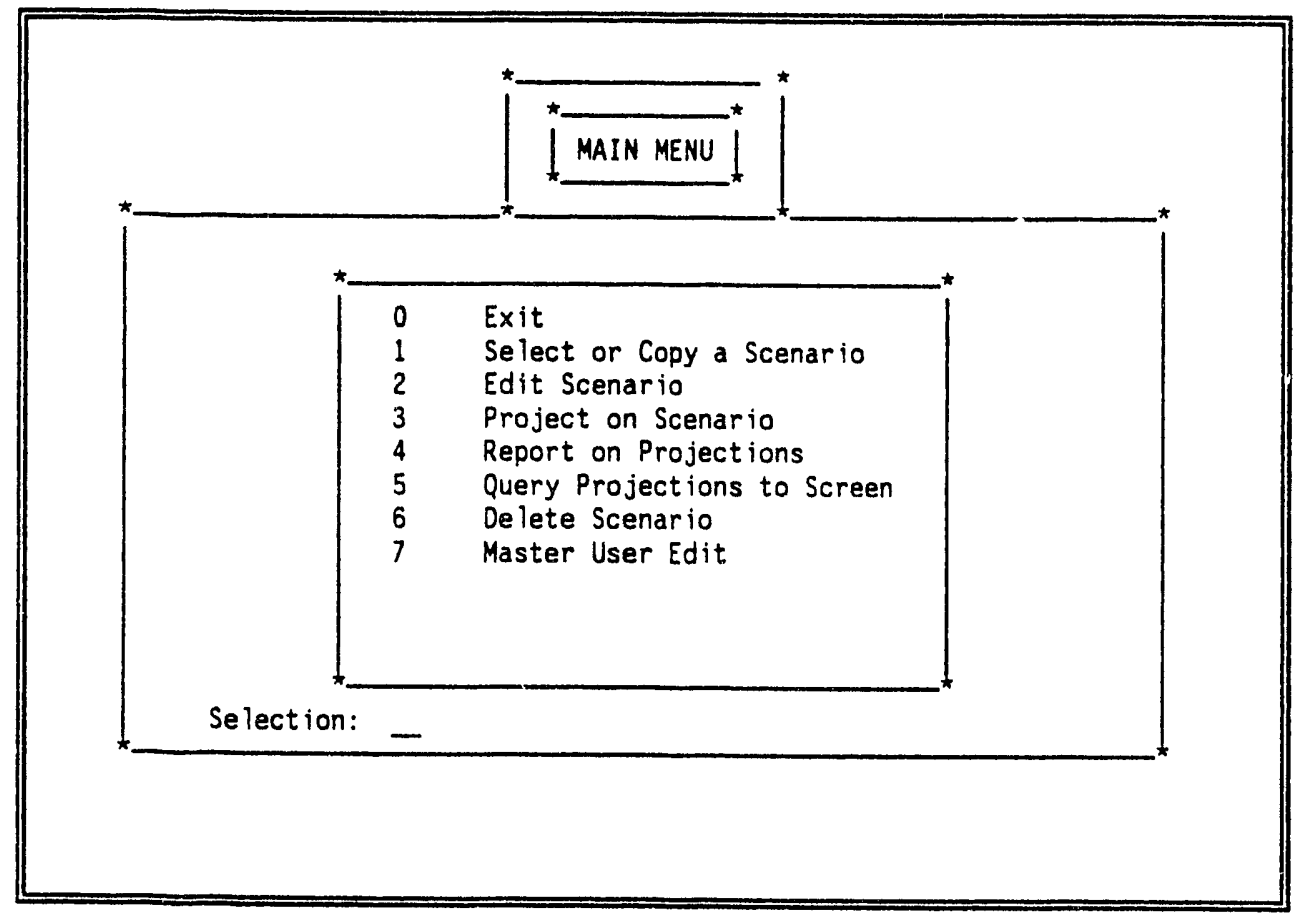

Figure 2. GTCC LLW Data Base - Main Menu 


\section{Logging Off}

To log off of the GTCC LLW Data Base:

1. Return to the GTCC LLW main menu (Figure 2).

Return to the GTCC LLW main menu from most submenus

by repeatedly typing 0 or pressing Exit until you reach the /u/users/userid> prompt.

2. At the GTCC LLW main menu, type 0 and press $<$ ENTER $>$.

3. Type exit or logout and press <ENTER $>$. 
Section 4

Logging On/Off 


\section{Select or Copy A Scenario}

You must select a scenario before you can perform any other options in the GTCC LLW Data Base.

1. To select or copy a scenario, type 1 and press <ENTER> from the main menu (see Figure 2, page 14). The following screen will appear.

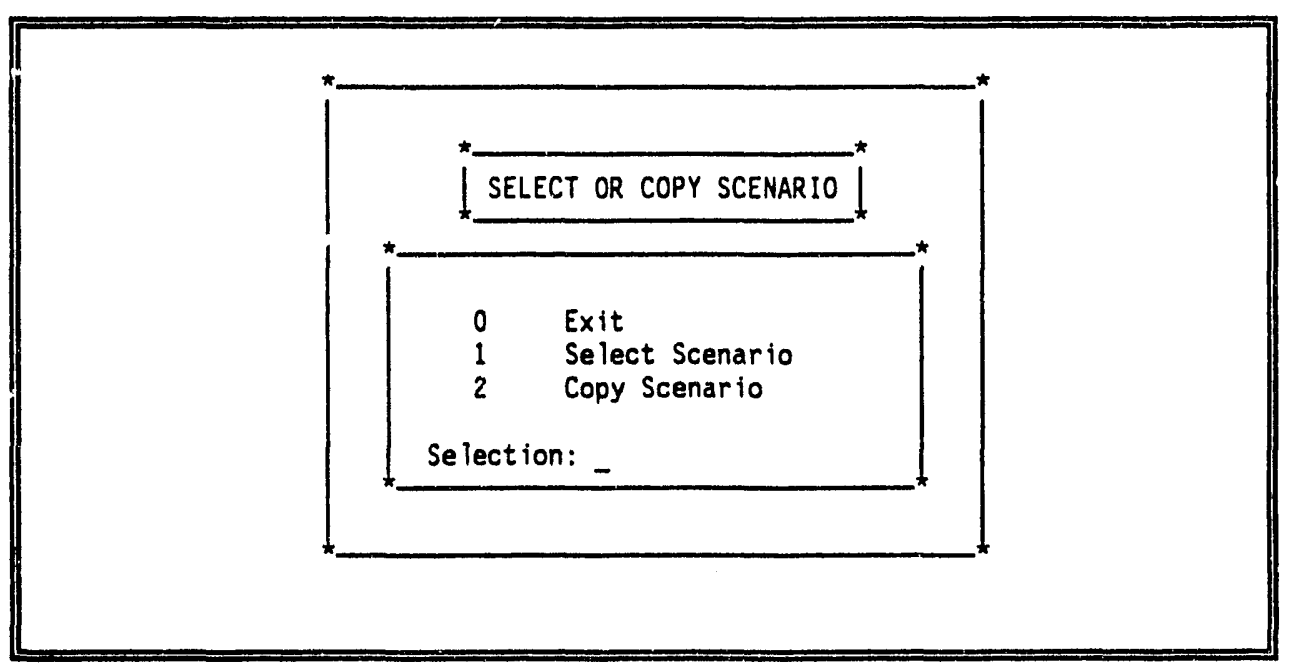

Figure 3. Select or copy a scenario menu.

2. For information on selecting a scenario, go to page 18.

For information on copying a scenario, go to page 22 


\section{Select A Scenario}

From this menu you can select and then either edit or project on a scenario.

1. To select a scenario, type 1 and press $<$ ENTER $>$ from the select or copy a scenario menu. The following screen

(Figure 4) will appear.

2. Use the up and down arrow keys to move to a desired selection. The current record will be highlighted.



Figure 4. Select a scenario menu. 
3. Press <ENTER > to select a scenario. The following screen should appear (Figure 5).



Figure 5. Display scenario menu.

4. Press <ENTER > to commit the selection. The following screen will appear (Figure 6). 


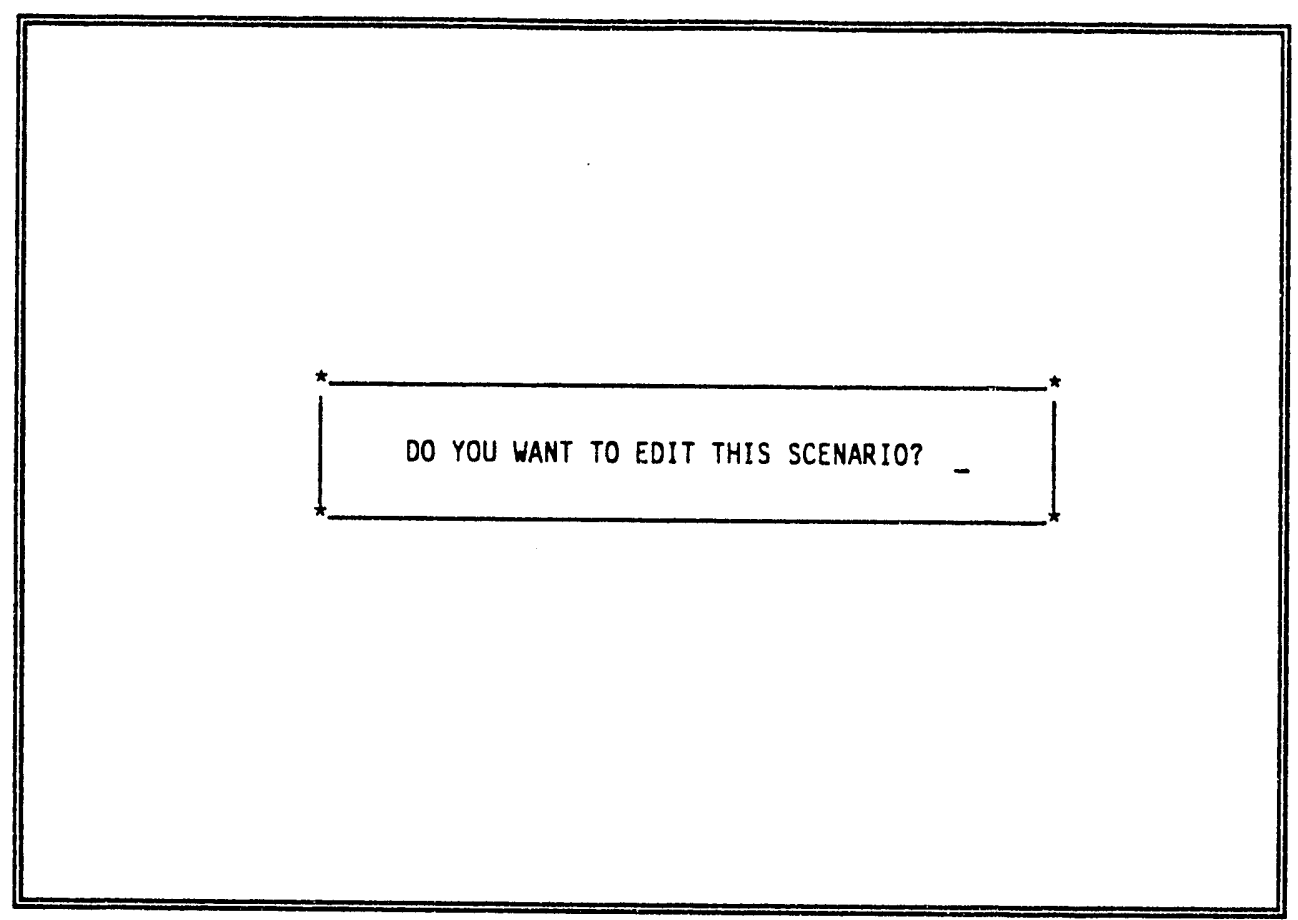

Figure 6. Continue editing scenario screen.

5. If you want to edit the scenario, type $Y$. This will take you directly to submenu 2, Edit Scenario, discussed in Section 6, page 27.

If you do not want to edit the scenario, type $\mathbf{N}$ and the screen shown in Figure 7 will appear. 


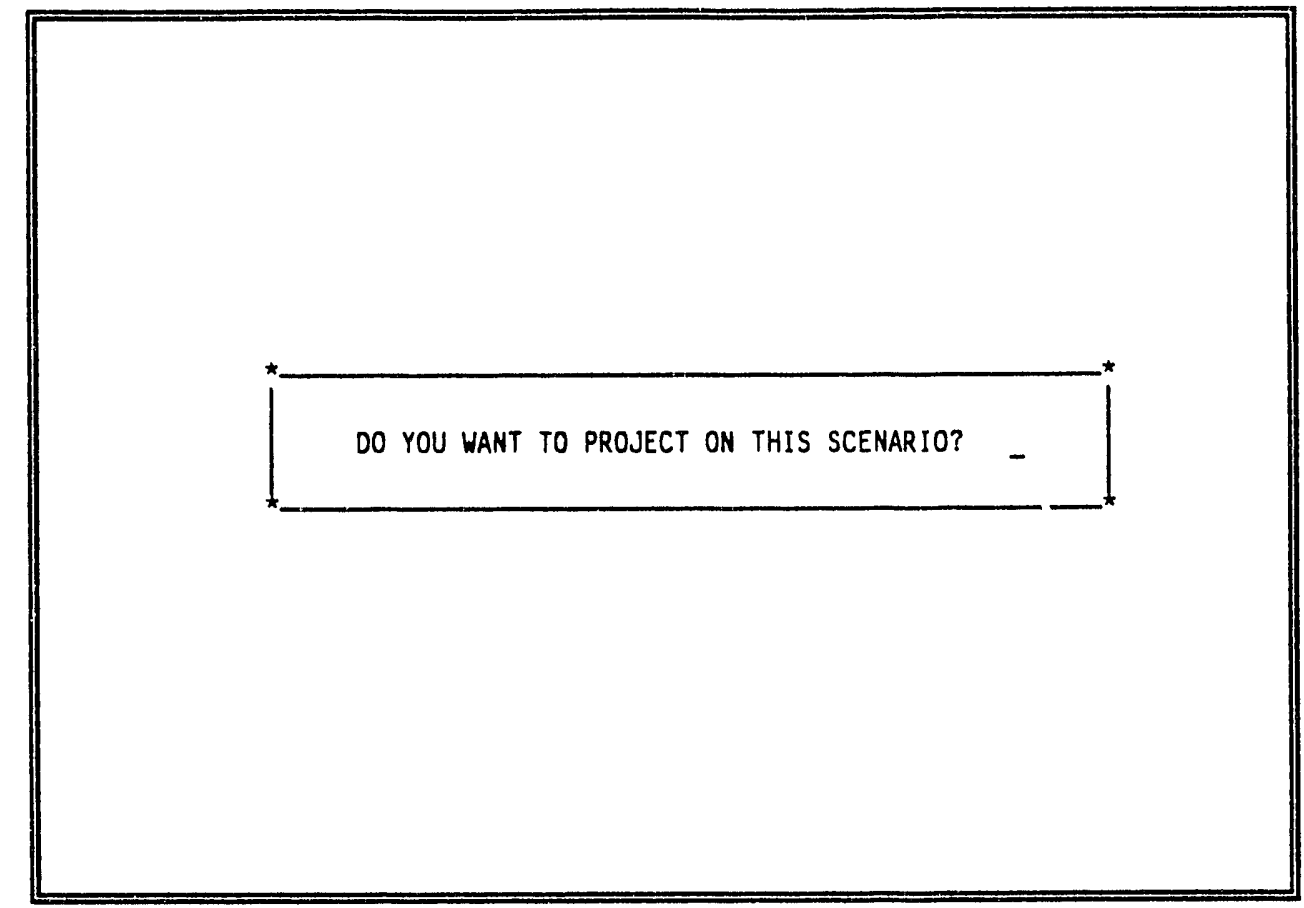

Figure 7. Continue projecting on scenario screen.

If you want to project on the scenario, type $Y$. This will take you directly to submenu 9, Project On This Scenario, discussed in Section 7, page 47.

If you do not want to project on the scenario, type $\mathbf{N}$ and exit this submenu. 


\section{Copy a Scenario}

This subsection describes how to copy a scenario.

1. Type 2 from the Select or Copy a Scenario submenu and press $<$ ENTER $>$. The following screen will appear (Figure 8).

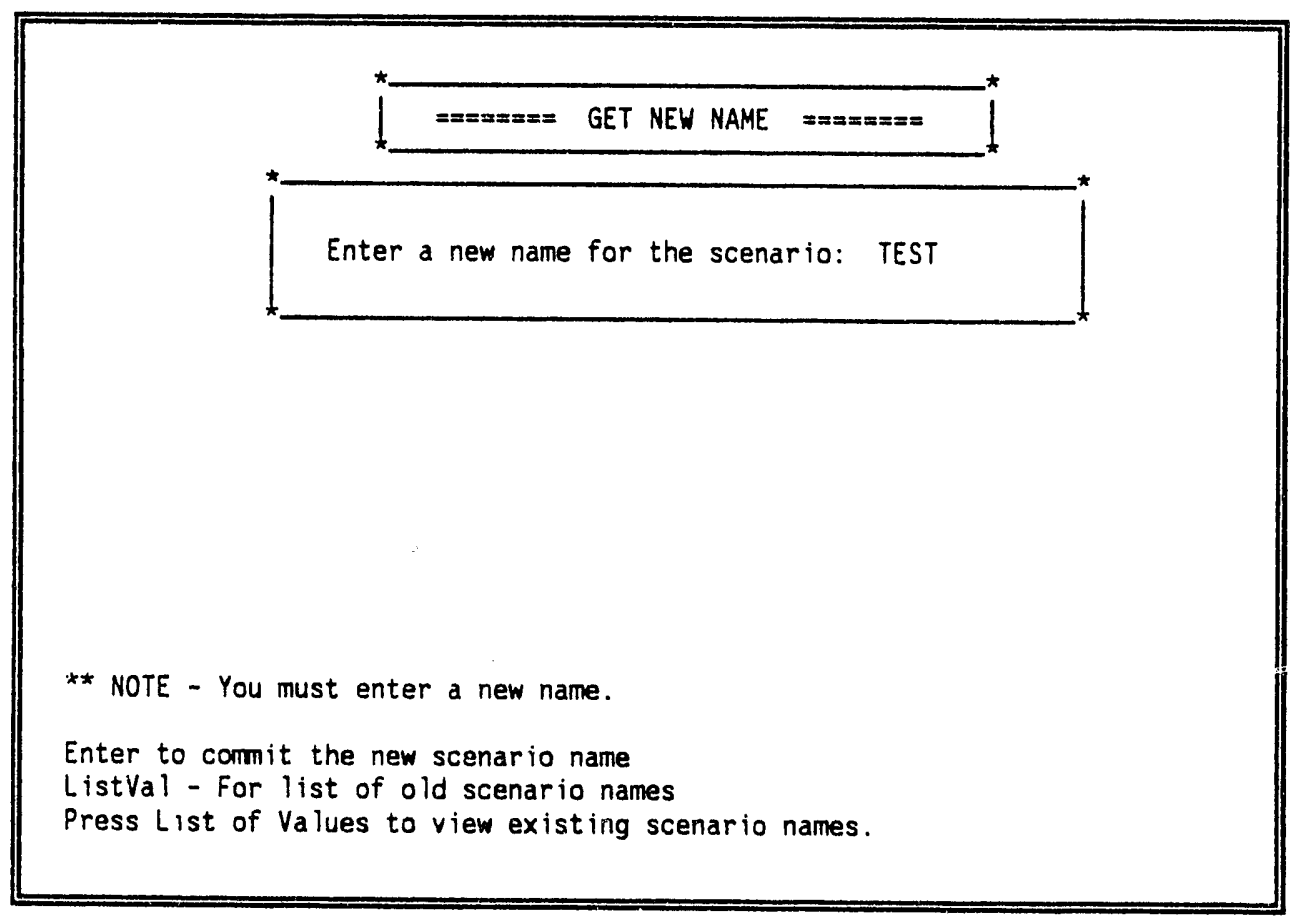

Figure 8. Get new name screen.

2. Type in a new name and press <ENTER >. (You cannot use a name from a current scenario.)

To see the list of current scenarios, as shown in Figure 9, press List of Values. 


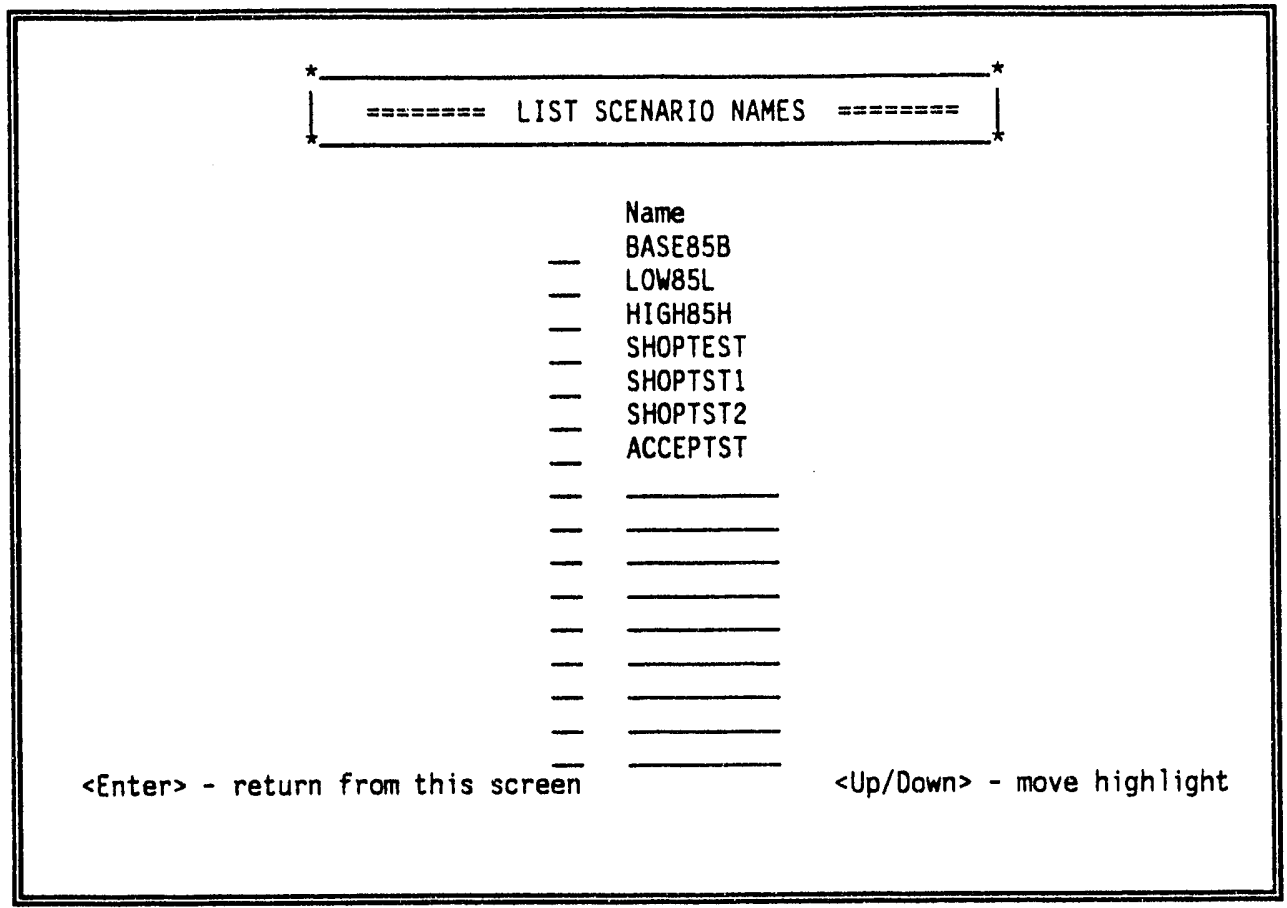

Figure 9. List of scenario names.

Press <ENTER> to exit. The following screen will appear (see Figure 10). 


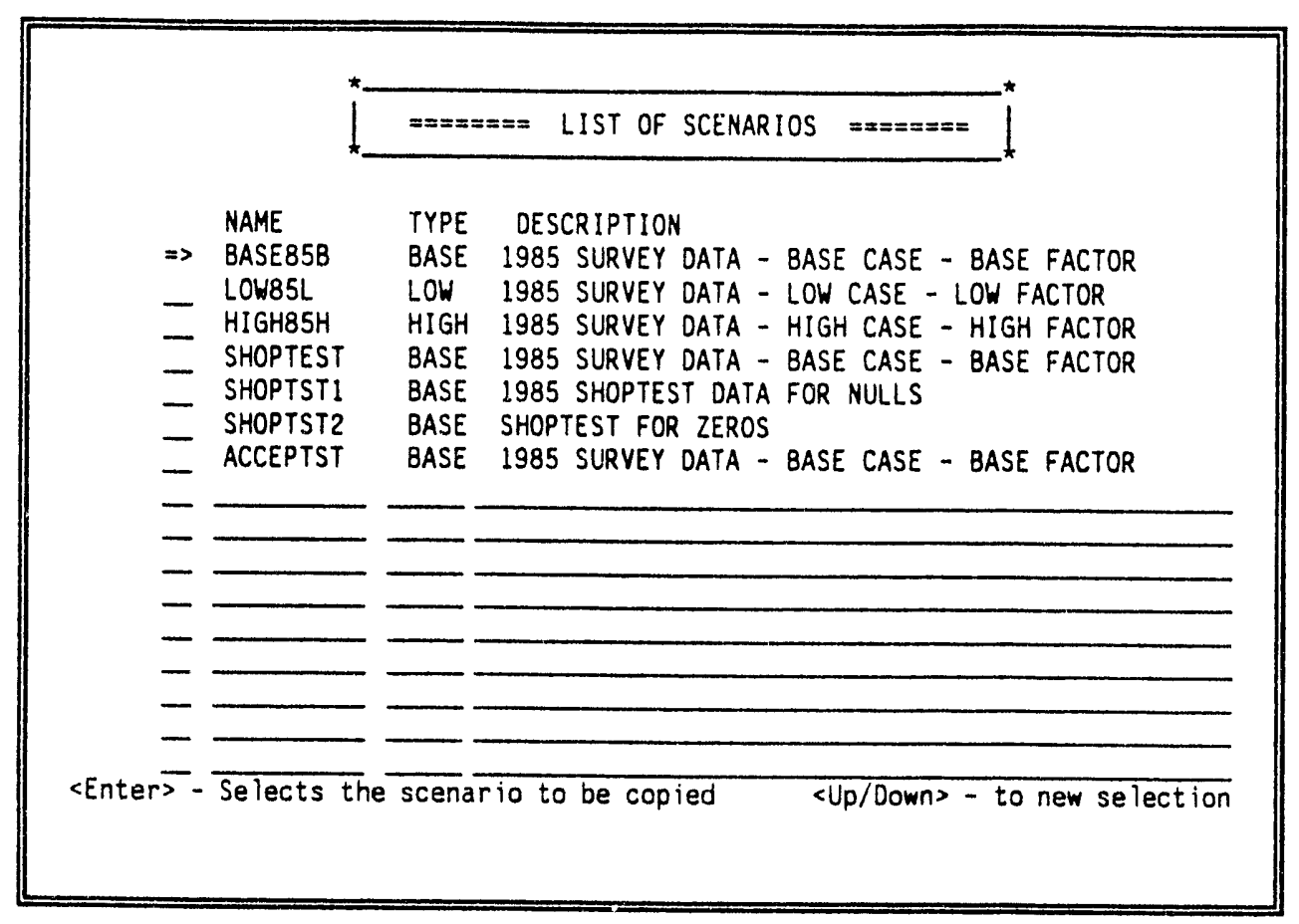

Figure 10. List of scenarios.

3. Use the up and down arrow keys to move to the desired scenario, and press <ENTER > to select a scenario. The following screen will appear (see Figure 11). 


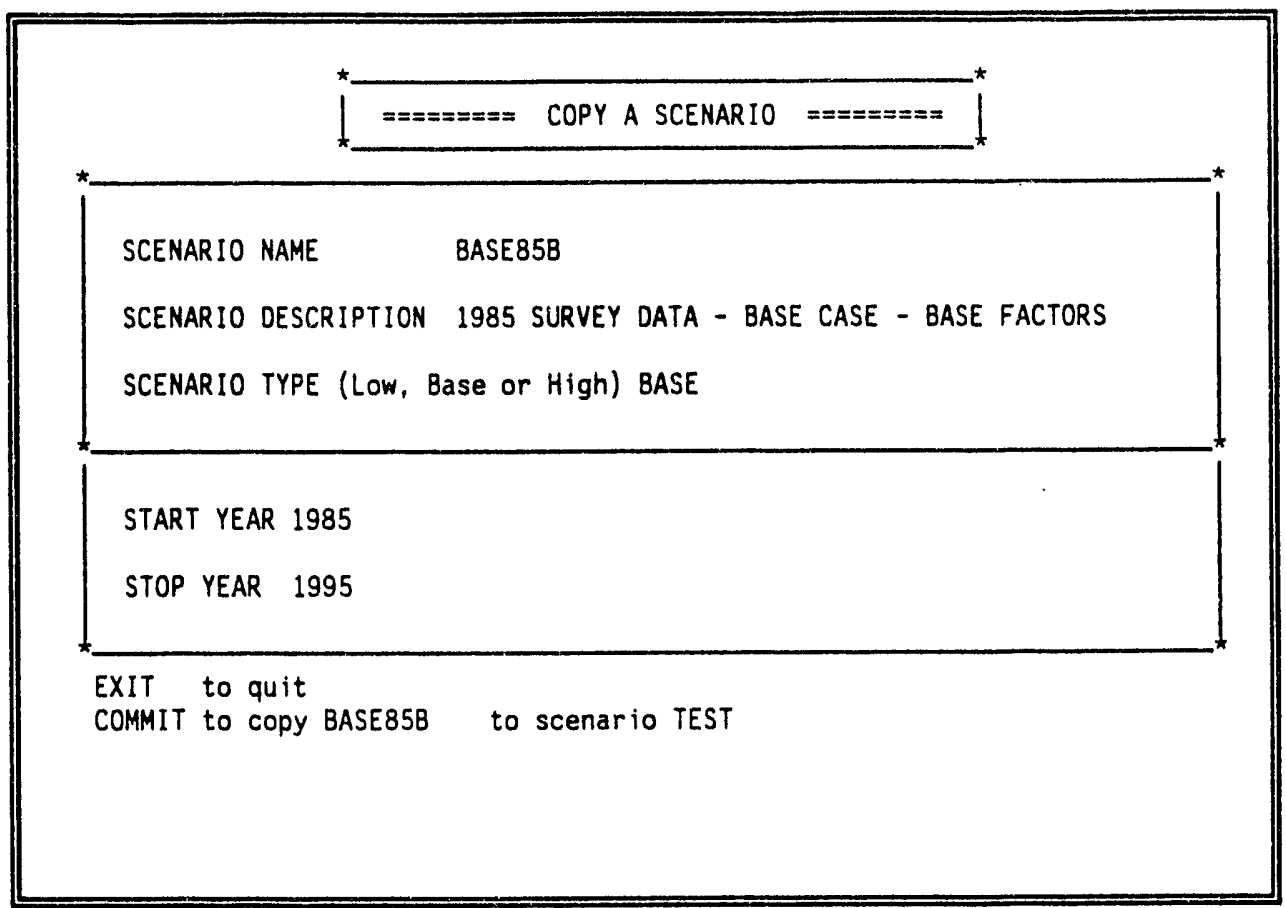

Figure 11. Copy scenario screen.

3. From the list of scenarios, press Commit to copy the highlighted scenario to the new name.

Press Exit to cancel the copy and return to the main menu. 
Section 5

Select or Copy a Scenario 


\section{Edit Scenario}

This section describes how to edit the tables that compose a scenario in the GTCC L.LW Data Base.

1. After you have selected a scenario (see Section 5, page 17), type 2 from the main menu and press $\langle$ ENTER $>$. The following screen will appear (Figure 12).

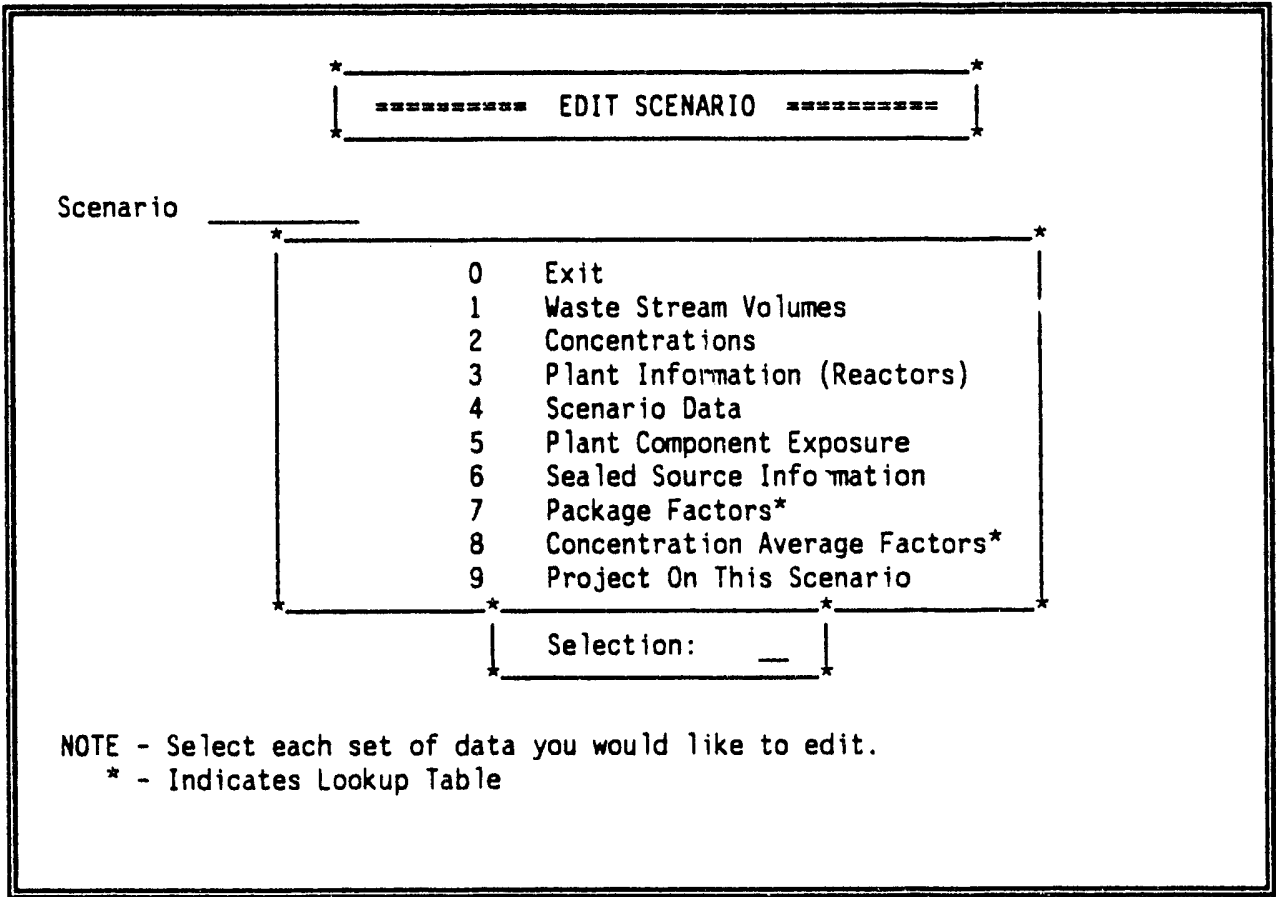

Figure 12. Edit scenario menu screen.

2. To make a selection, type any of the numbers for the presented selections and press $<$ ENTER $>$. The following subsections describe the Edit Scenario selections in detail. 


\section{Waste Stream Volumes}

1. From the Edit Scenario menu, type 1 and press <ENTER> to edit the waste stream volume. The following screen will appear (Figure 13).

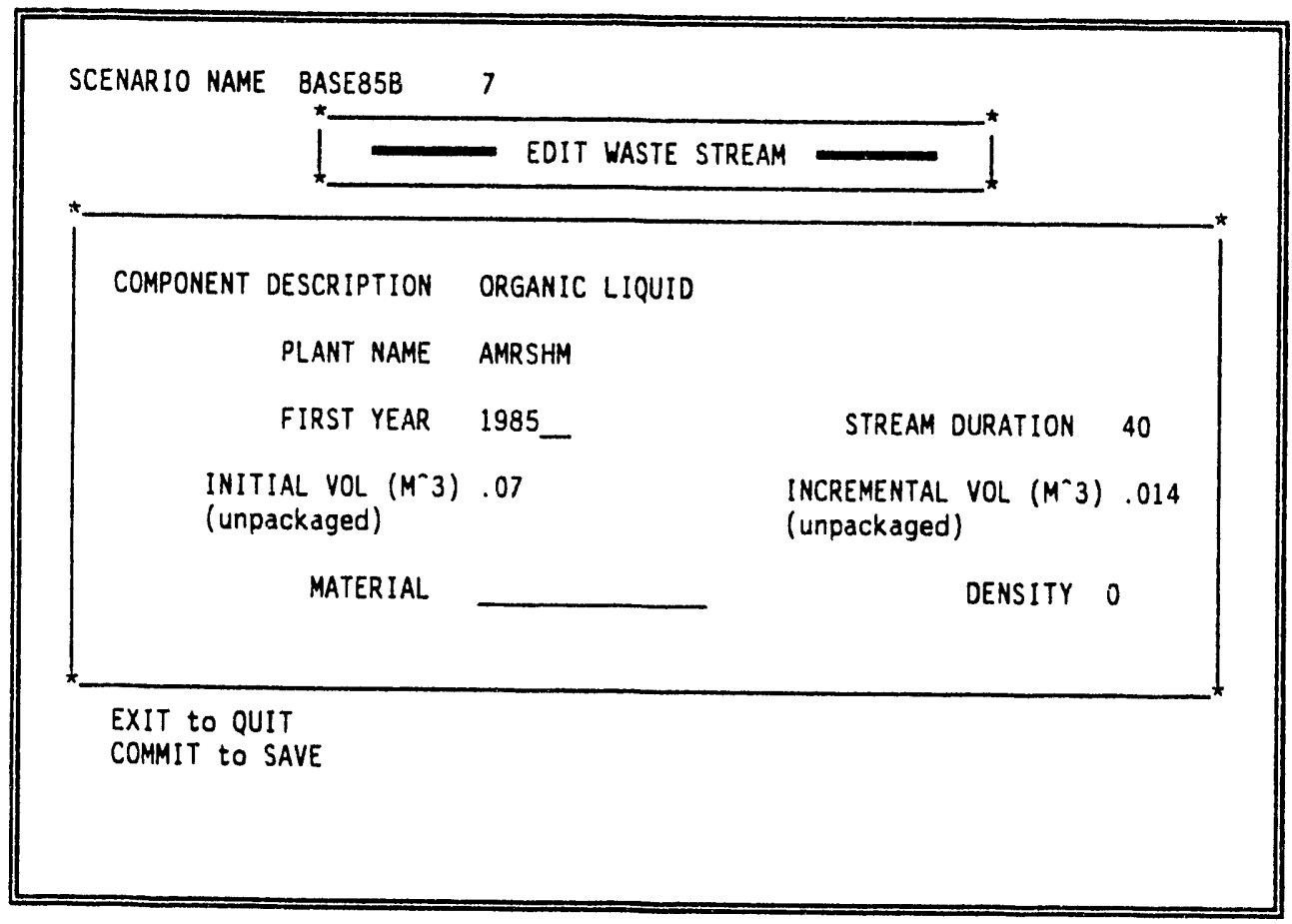

Figure 13. Edit waste stream screen.

On the edit screens, one or more fields comprise the key that uniquely identifies that record. This key information may not be edited, as the record would lose its uniqueness.

The fields on this screen that may be modified are

- $\quad$ First year of the waste stream (default 1985) 
- $\quad$ Stream duration (number of years the waste stream will continue to generate waste, 0-999)

- Initial volume of the waste stream in cubic meters

- Incremental annual volume of the waste stream in cubic meters

- Material the waste stream is constructed of (alphanumeric string)

- Density of the waste stream in kilograms/cubic meter.

2. Use the Next field key to move the field you want to modify.

3. Press Commit to save your changes. Press Exit to quit this option and cancel your changes, if any.

4. Press Exit to quit. The system will ask you if you want to commit your changes before you quit. Type $\mathbf{Y}$ or $\mathbf{N}$ and press <ENTER>. 


\section{Edit Concentrations}

1. From the Edit Scenario menu, type 2 and press <ENTER > to edit the waste stream concentrations. The following screen will appear (Figure 14).

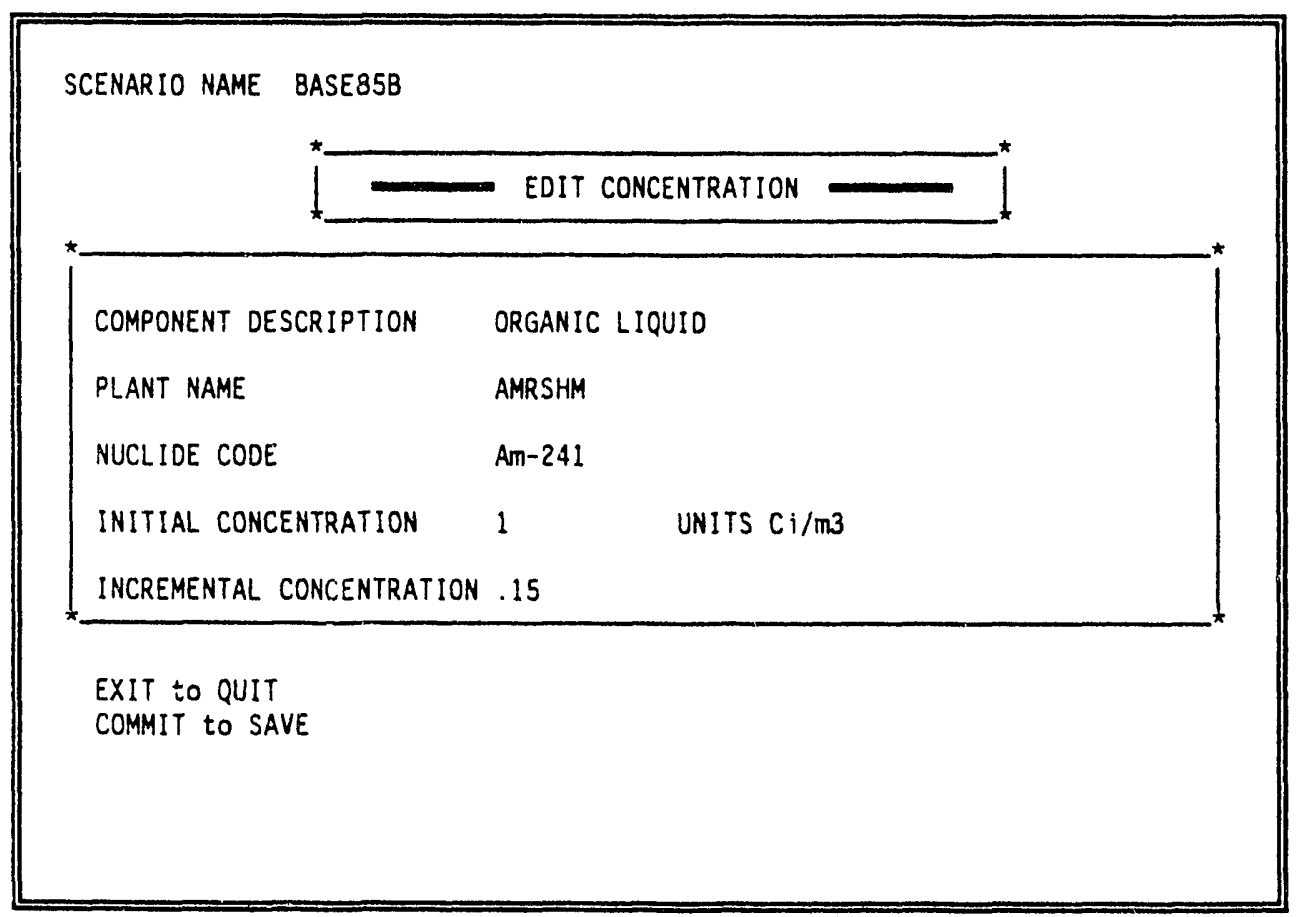

Figure 14. Edit concentration screen.

The fields that may be edited on this screen include

- Nuclide code, an alphanumeric string of six characters

- Initial concentration of the specified radionuclide activity per volume of the waste stream in curies per cubic meter units 
- Incremental concentration of the radionuclide activity that will be added annually.

2. Use the Next field key to move the field you want to modify.

3. Press Commit to save your changes. Press Exit to quit this option and cancel your changes, if any.

4. Press Exit to quit. The system will ask you if you want to commit your changes before you quit. Type $\mathbf{Y}$ or $\mathbf{N}$ and press $<$ ENTER $>$. 


\section{Plant Information (Reactors)}

1. From the Edit Scenario menu, type 3 and press <ENTER> to edit plant (reactor) information. The following screen will appear (Figure 15).

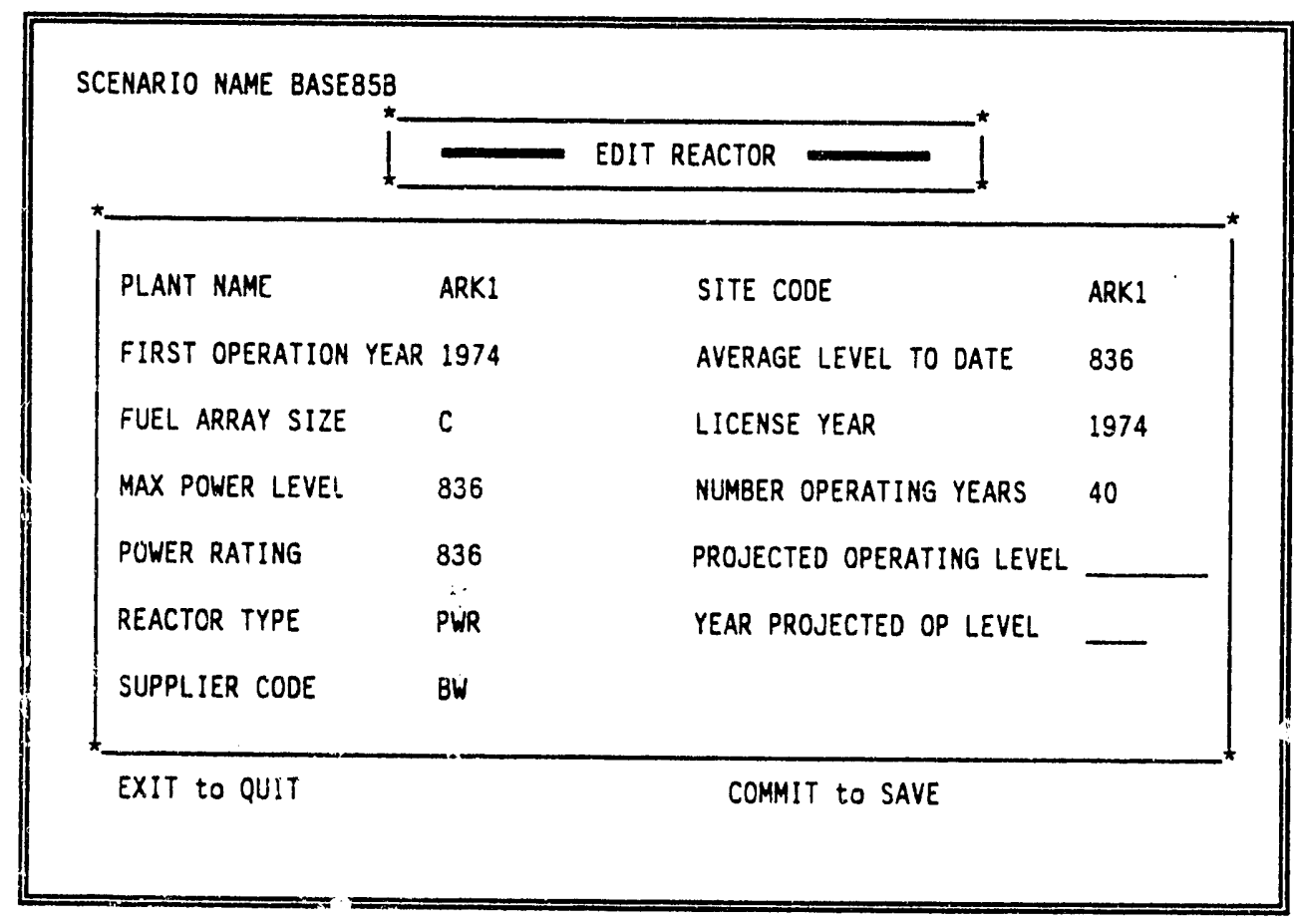

Figure 15. Edit reactor screen.

The tields that may be edited on this sreen are

- First operation year, the first year the plant began operations.

- $\quad$ Average level to date, the average percentage of maximum capacity that the plant has run since 
commencement of operations. At this time, the average level to date contains the power rating of the plant, as this data was not available.

- Fuel array size, the code that corresponds to the supplier that built the reactor, and the reactor type. See Table 2 below for a listing of fuel array size codes and their descriptions.

- License year, the year the operations license was issued to the plant.

- Max power level, the maximum power level at which the plant operates. This field contains the same number as the power rating.

- Number of operating years, the number of years the plant is expected to operate (usually 40 years).

- Power rating, the megawatt thermal rating for the plant.

- $\quad$ Projected operating level, the percentage of maximum power level at which the plant is estimated to operate.

Table 2 Reactor reference table.

\begin{tabular}{||l|c|c|c|c|c|c||}
\hline Code & A & B & C & D & E & F \\
\hline \hline Supplier & GE & GE & BW & CE & WEST & WEST \\
\hline $\begin{array}{l}\text { Reactor } \\
\text { type }\end{array}$ & BWR4 & BWR6 & PWR & PWR & $\begin{array}{c}\text { PWR- } \\
\text { mid size }\end{array}$ & $\begin{array}{c}\text { PWR- } \\
\text { large }\end{array}$ \\
\hline
\end{tabular}


- $\quad$ Reactor type, either BWR (boiling water reactor), PWR (pressurized water reactor), or HTGR (high temperature gas-cooled reactor).

- Years at projected operation level, the number of years the reactor is expected to operate at the projected operating level.

- Supplier code, the descriptor of the company that manufactured the reactor (CE-Combustion Engineering, BW-Babcock and Wilcox, GE-General Electric, or WEST-Westinghouse).

2. Use the Next field key to move the field you want to modify.

3. Press Commit to save your changes. Press Exit to quit this option and cancel your changes, if any.

4. Press Exit to quit. The system will ask you if you want to commit your changes before you quit. Type $\mathbf{Y}$ or $\mathbf{N}$ and press $<$ ENTER $>$. 


\section{Scenario Data}

1. From the Edit Scenario menu, type 4 and press <ENTER> to edit scenario data. The following screen will appear

(Figure 16).

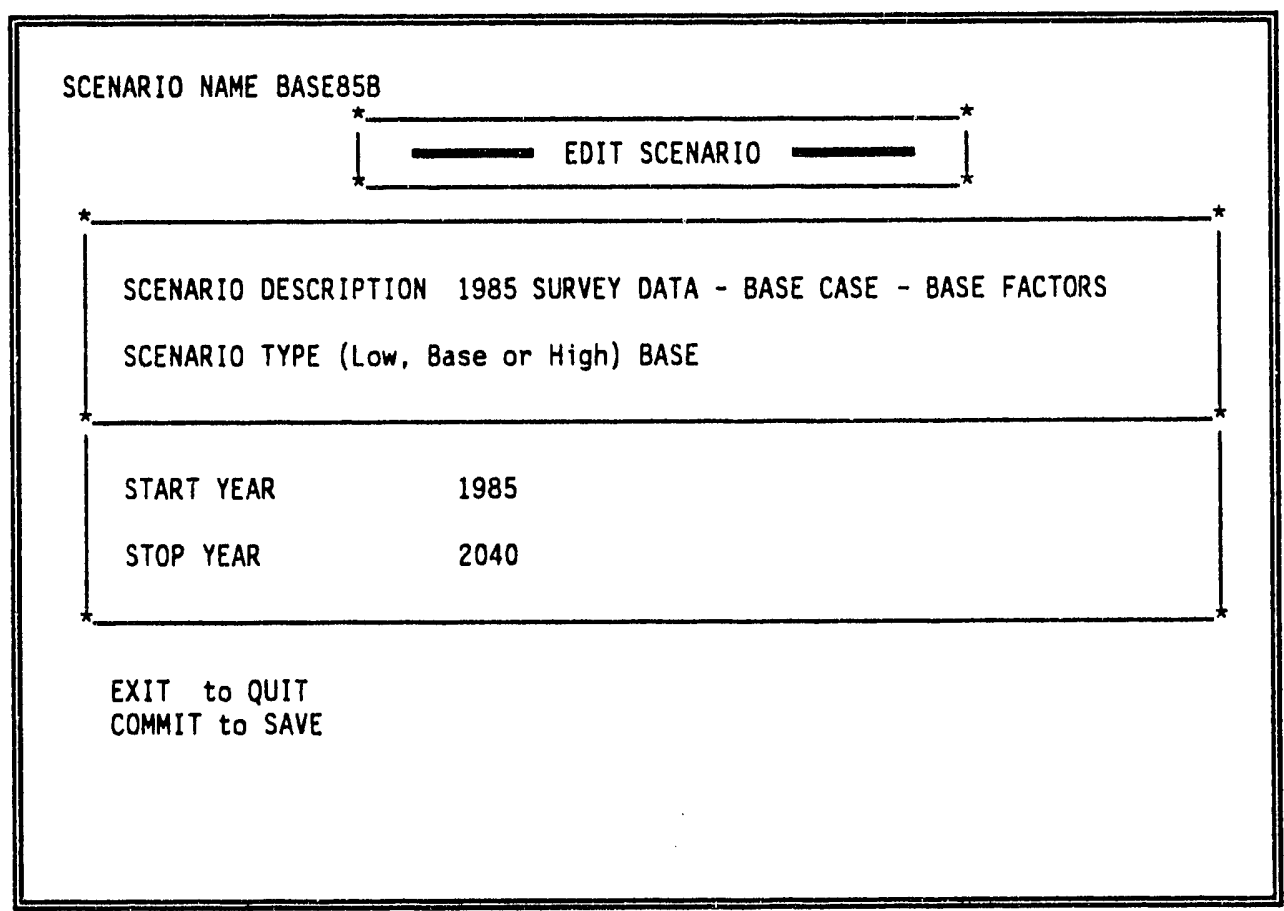

Figure 16. Edit scenario sqreen.

Only the start year and stop year fields may be edited on this screen. Scenarios may only be added by copying an existing scenario to ensure all associated records are created. Insert record and Delete record are disabled for this screen. To edit scenario type, you must delete the scenario and re-create it with a different scenario type. This method of editing the scenarios will prevent inconsistent scenario information. Use 
the Delete option (option 6 from the main menu, see page 57) to delete the scenario.

2. Use the Next field key to move the field you want to modify.

3. Press Commit to save your changes. Press Exit to quit this option and cancel your changes, if any.

4. Press Exit to quit. The system will ask you if you want to commit your changes before you quit. Type $\mathbf{Y}$ or $\mathbf{N}$ and press $<$ ENTER $>$. 


\section{Plant Component Exposure}

1. From the Edit Scenario menu, press 5 and $<$ ENTER $>$ to edit plant component exposure. The following screen will appear (Figure 17).

SCENARIO NAME BASE85B



Figure 17. Plant component exposure screen.

Data for the plant component exposure screen is not available at this time. However, when that data becomes available, the average number of years will be the only field available for editing purposes. 
2. Use the Next field key to move the field you want to modify (in this option, you can only edit the field average number of years).

3. Enter the number of years the component was exposed to a radioactive flux field at the specified plant.

4. Press Commit to save your changes. Press Exit to quit this option and cancel your changes, if any.

4. Press Exit to quit. The system will ask you if you want to commit your changes before you quit. Type $\mathbf{Y}$ or $\mathbf{N}$ and press $<$ ENTER>. 


\section{Sealed Source Information}

1. From the Edit Scenario menu, type 6 and press <ENTER> to edit sealed source information. The following figure will appear (Figure 18).

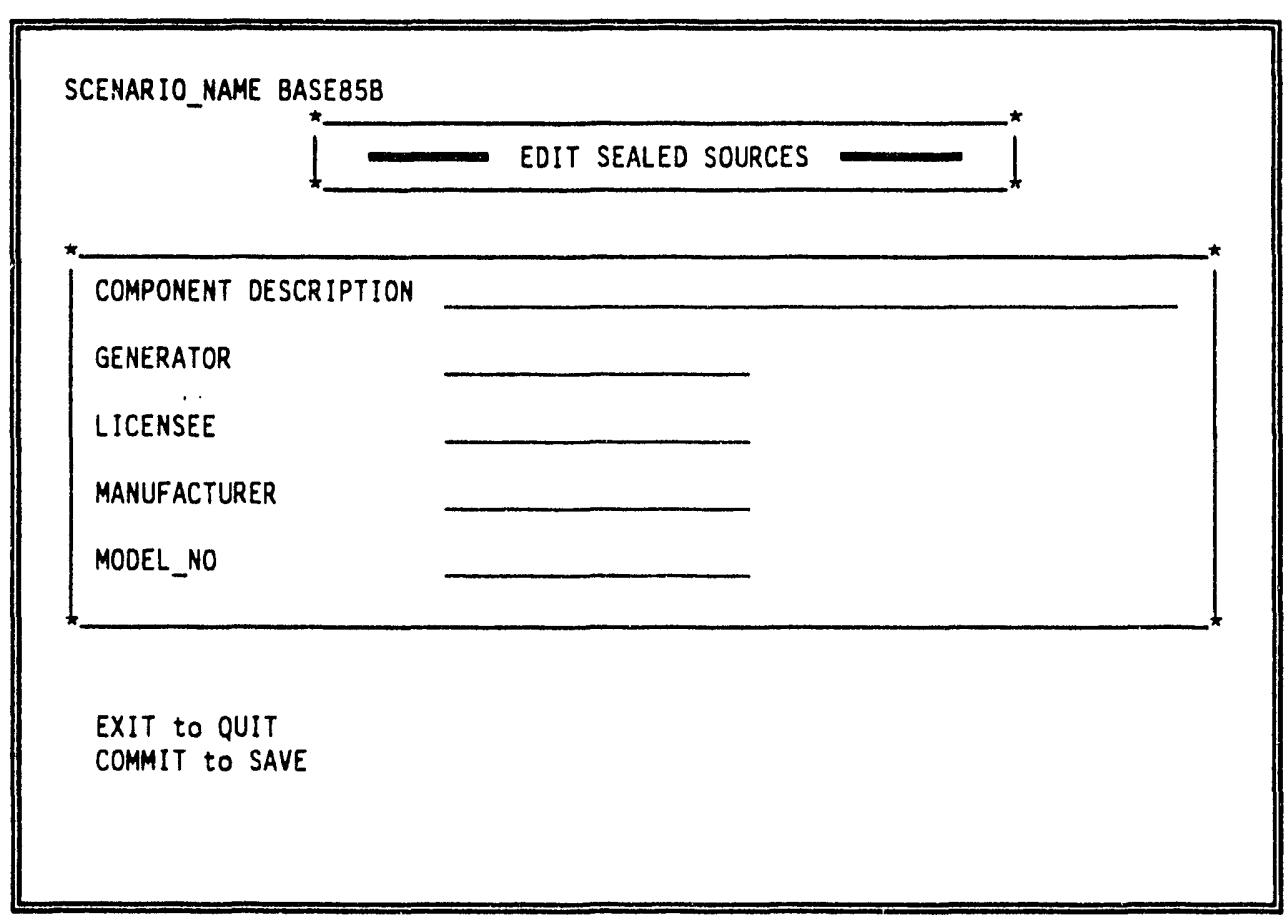

Figure 18. Sealed source information screen.

Data for the Sealed Source Information screen is not available at this time. However, the following fields may be edited when the data becomes available:

- Generator, the name of the facility/company that generated the sealed source waste. 
- Licensee, the person licensed to possess the sealed source. The licensee may be the same entity as the generator.

- Manufacturer, the person/company that manufactured the sealed source.

- Model no, the model number of the sealed source.

2. Use the Next field key to move the field you want to modify.

3. Press Commit to save your changes. Press Exit to quit this option and cancel your changes, if any.

4. Press Exit to quit. The system will ask you if you want to commit your changes before you quit. Type $\mathbf{Y}$ or $\mathbf{N}$ and press $<$ ENTER $>$. 


\section{Package Factors}

1. From the Edit Scenario menu, type 7 and press $<$ ENTER $>$ to edit package factors. The following screen will appear (Figure 19).

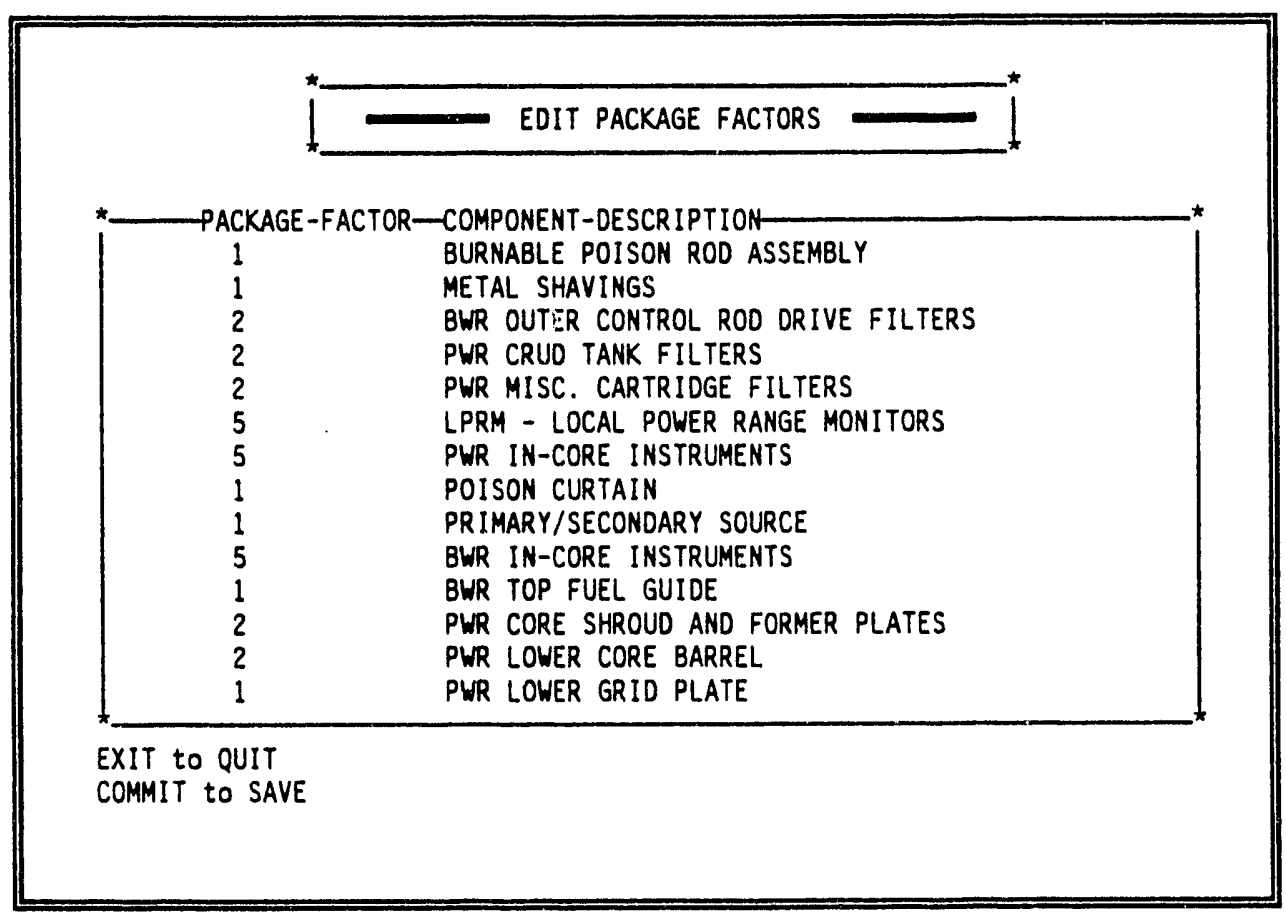

Figure 19. Package factor screen.

The component description can only be modified through the Edit Component Option on the Master Edit Option (7). Package factor is the only field on this screen that may be modified.

2. Use the Next field key to move the field you want to modify. 
3. Enter the number that indicates the appropriate volume multiplier for the specified component. The package factor, multiplied by the unpackaged volume, will indicate the packaged volume of the waste stream once the waste stream has been processed and packaged.

4. Press Commit to save your changes. Press Exit to quit this option and cancel your changes, if any.

5. Press Exit to quit. The system will ask you if you want to commit your changes before you quit. Type $\mathbf{Y}$ or $\mathbf{N}$ and press $<$ ENTER $>$. 


\section{Concentration Average Factors}

1. From the Edit Scenario menu, type 8 and press <ENTER> to edit concentration average factors. The following screen will appear (Figure 20).

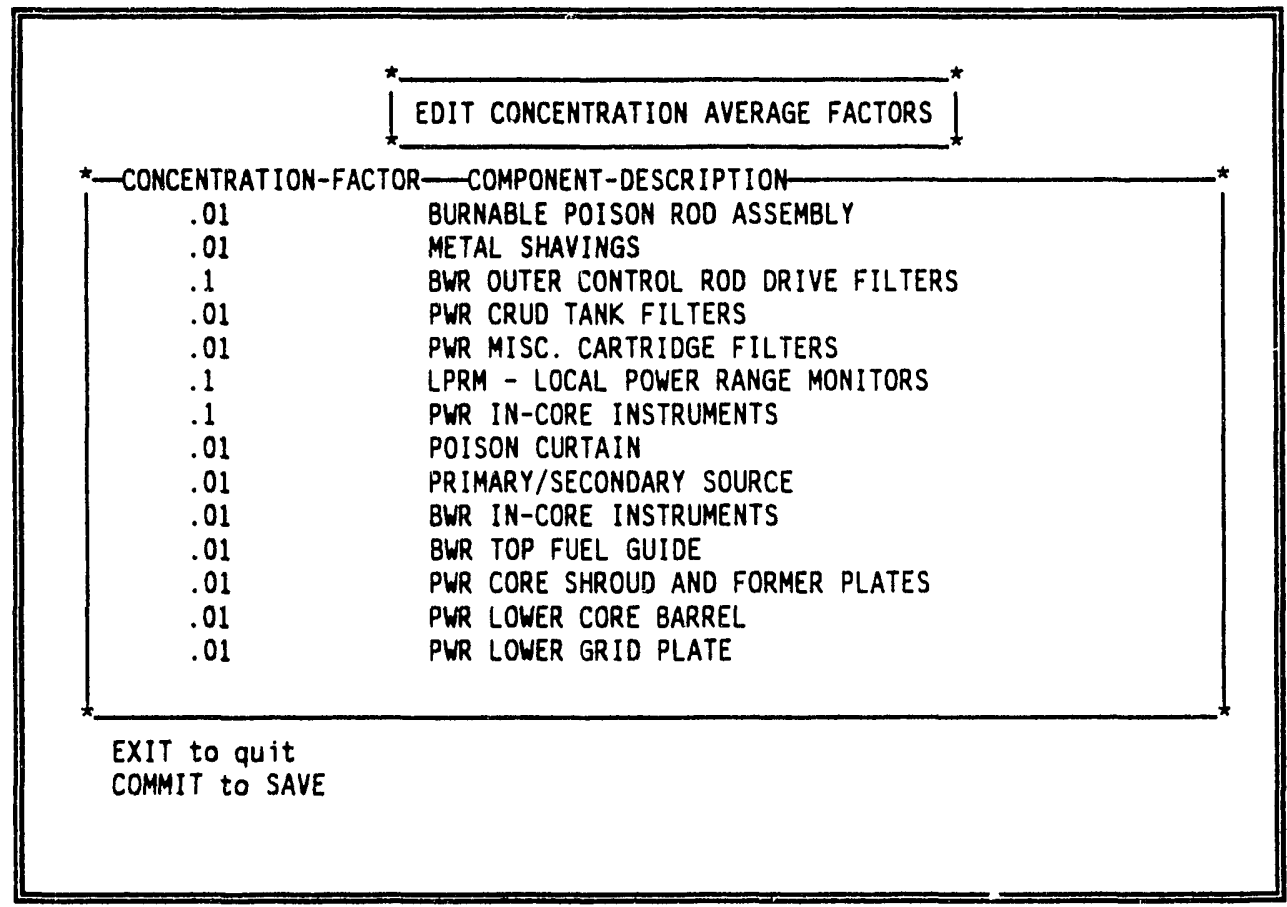

Figure 20. Concentration average factors.

The concentration average factor is the only field that may be modified on this screen.

2. Use the Next field key to move the field you want to modify.

3. Enter a number that indicates the concentration averaging divisor for the specified component. Concentration averaging 
is the act of combining components with different radionuclide activities to lessen the overall radionuclide activity of the packaged waste stream.

4. Press Commit to save your changes. Press Exit to quit this option and cancel your changes, if any.

5. Press Exit to quit. The system will ask you if you want to commit your changes before you quit. Type $\mathbf{Y}$ or $\mathbf{N}$ and press $<$ ENTER $>$. 


\section{Project on This Scenario}

To project on the scenario, type 9 and press <ENTER>. From here, you can follow the directions in Section 7, Project on Scenario, on page 47. 
Section 6

Edit Scenario 


\section{Project on Scenario}

1. From the main menu, type 3 and press $<$ ENTER $>$ to make a projection based on scenario. The following screen will appear (Figure 21).

You can also project on scenario from the Select or Copy a Scenario and Edit Scenario options.



Figure 21. Project on scenario screen.

2. Press Commit to project on scenario. Press Exit to cancel and return to the main menu. If you select to commit, the following screen should appear (Figure 22). 




Figure 22. Run calculations screen.

3. If you want to run volume calculations, type $Y$ and press $<$ ENTER >. If not, type $\mathbf{N}$ and press <ENTER>.

4. If you want to run activity calculations, type $Y$ and press $<$ ENTER >. If not, type $\mathbf{N}$ and press <ENTER>.

5. Press Commit to exit to the main menu.

Note: Running either calculation may take a few minutes.

All calculated volumes and activities associated with this scenario will be overwritten with new calculations. Type $\mathbf{N}$ at both options to preserve the existing calculated volumes and activities. 


\section{Report on Projections}

1. To report on projections, type 4 and press $<$ ENTER $>$ from the main menu. The following screen will appear (Figure 23).



Figure 23. Report on projections screen.

2. Type the number of the report you want and press $<$ ENTER $>$.

3. For options 1 to 5 , the following screen will appear (Figure 24). 


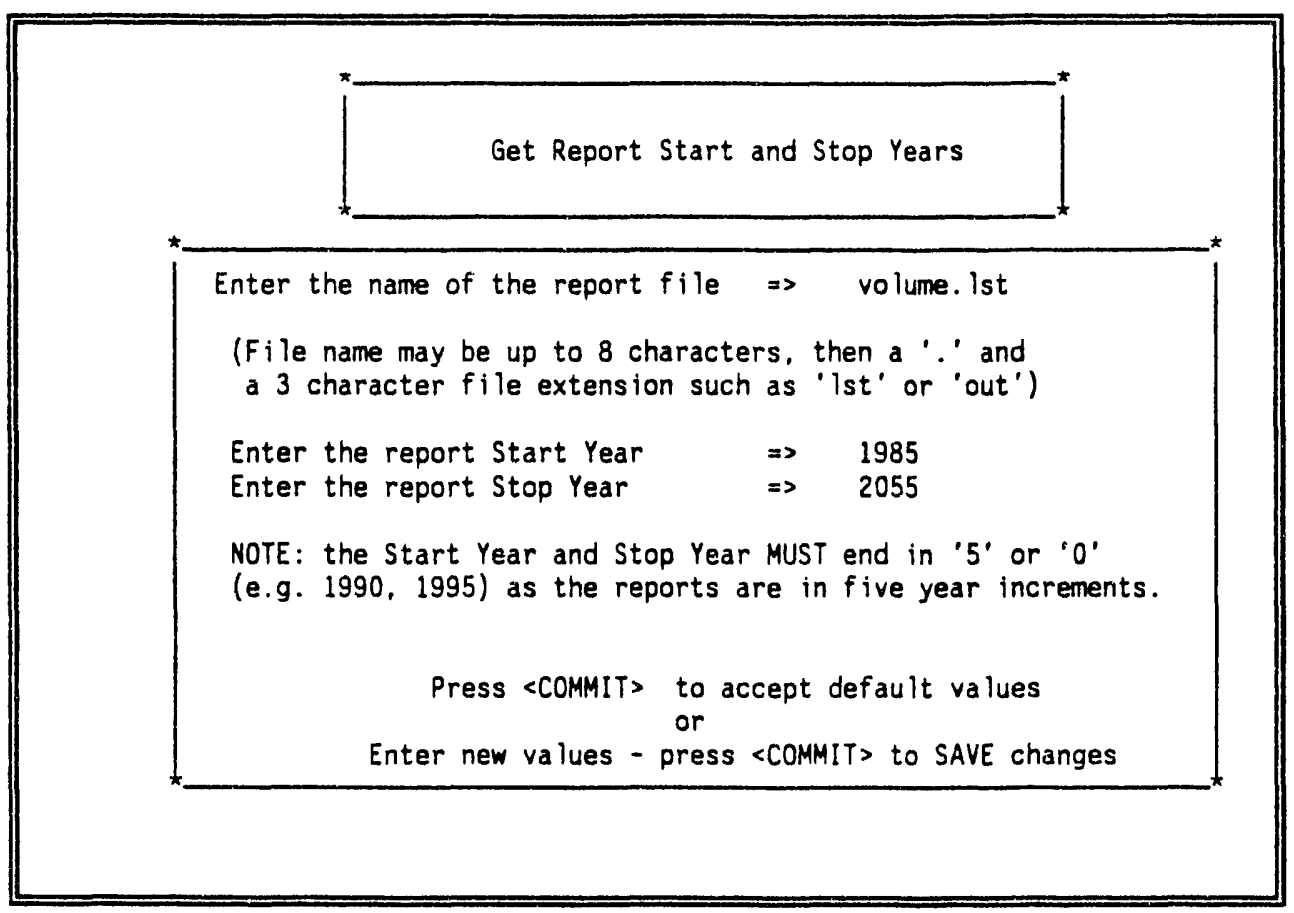

Figure 24. Get report screen.

Reports 1 to 5 report the volumes and activities in five-year increments.

These results are shown in the following format:

Non-activated metals waste

Operational waste

Decommissioning waste

Activated metals waste

Operational waste

Decommissioning waste

Example reports are contained in the appendix. 
4. Enter new values and press Commit to save changes.

You can also accept the default values by pressing Commit.

For option 6, GTCC LLW Characterization Reports, the following screen will appear (Figure 25).

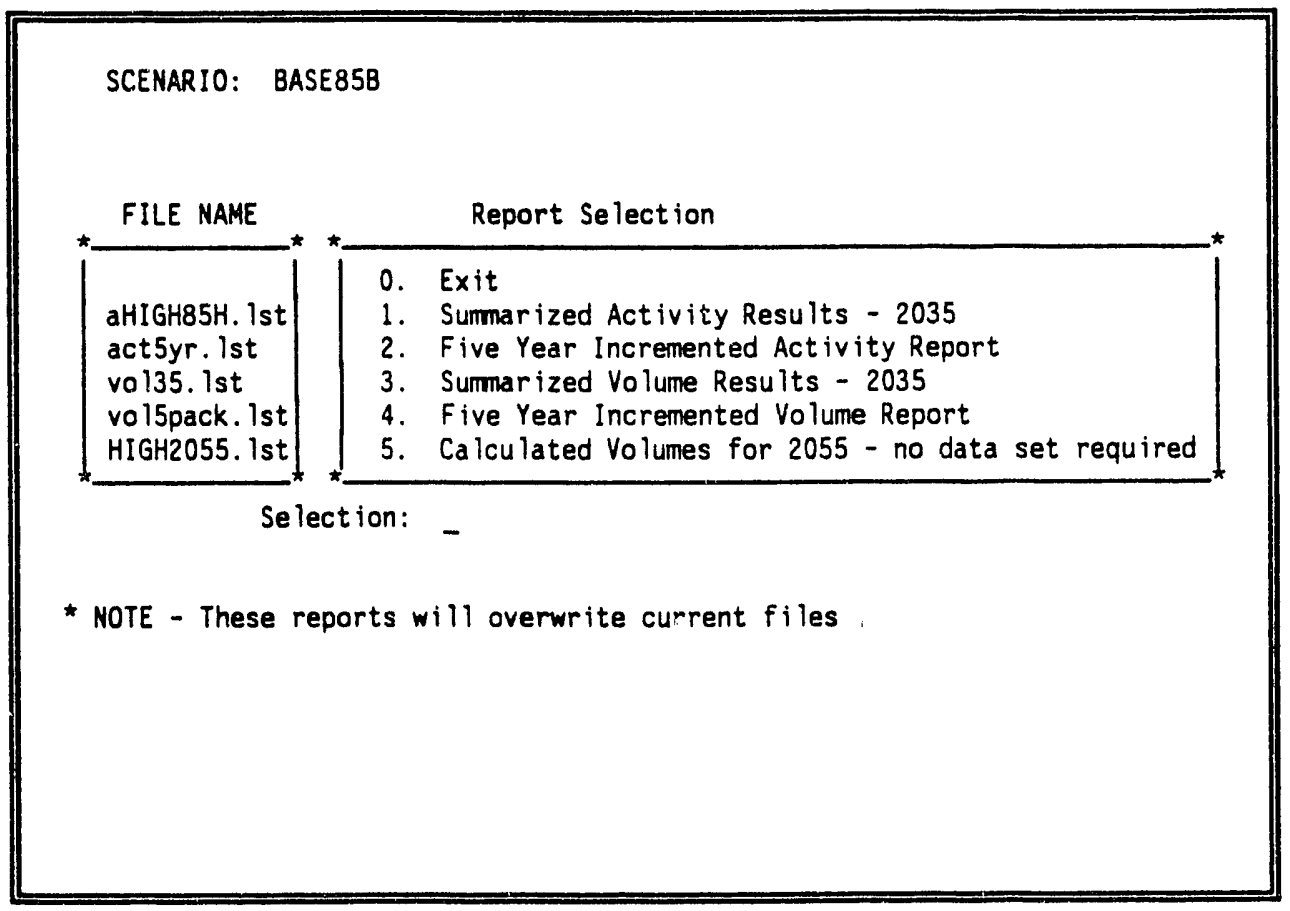

Figure 25. GTCC LLW characterization report screen.

1. Type the number of the desired report, and press $<$ ENTER > to generate the report.

2. After the report has run, type 0 and press $<$ ENTER $>$ to exit to the main menu, or report additional projections. 
3. The reports will be written to the user's home directory (/u/users/userid), with the specified report name.

NOTE: All existing report files will be overwritten with the new reports.

4. To print the report, you must use the 3Com or Excelan File Transfer Protocol (FTP) software to put the report file on your PC. You may then print the file to a printer using landscape print mode. This FTP process must be used until a server printer is installed and configured. At that time, an update to this page will be issued, instructing users how to print report files.

To transfer the report file to the PC:

1. Exit the GTCC LLW system by pressing 0 at the main menu. Log off the data base server (see Section 4, page ).

2. From the DOS prompt, type c:lftp boink1.

3. At the userid: prompt, enter the userid and press $<$ ENTER >. Type the password and press <ENTER>.

4. Type get <filename> and press <ENTER>. This command gets the report from the server and transfers the file to the PC.

To transfer many files at one time, type c:|mget <filenames>, where filenames may include wildcard characters such as ${ }^{*}$.Rpt. The user will then be prompted for defualt PC filenames. Press <ENTER> to accept the default filenames. The files will be placed in the current directory on the PC. 
Refer to the 3Com or Excelan documentation or the system administrator for more information. 
Section 8

Report on Projections 


\section{Query Projections to Screen}

You must first select a scenario before you can query projections to screen (see Section 5, page 17).

1. To query projections to screen, type $\mathbf{5}$ and press <ENTER>. The following screen will appear (Figure 26).

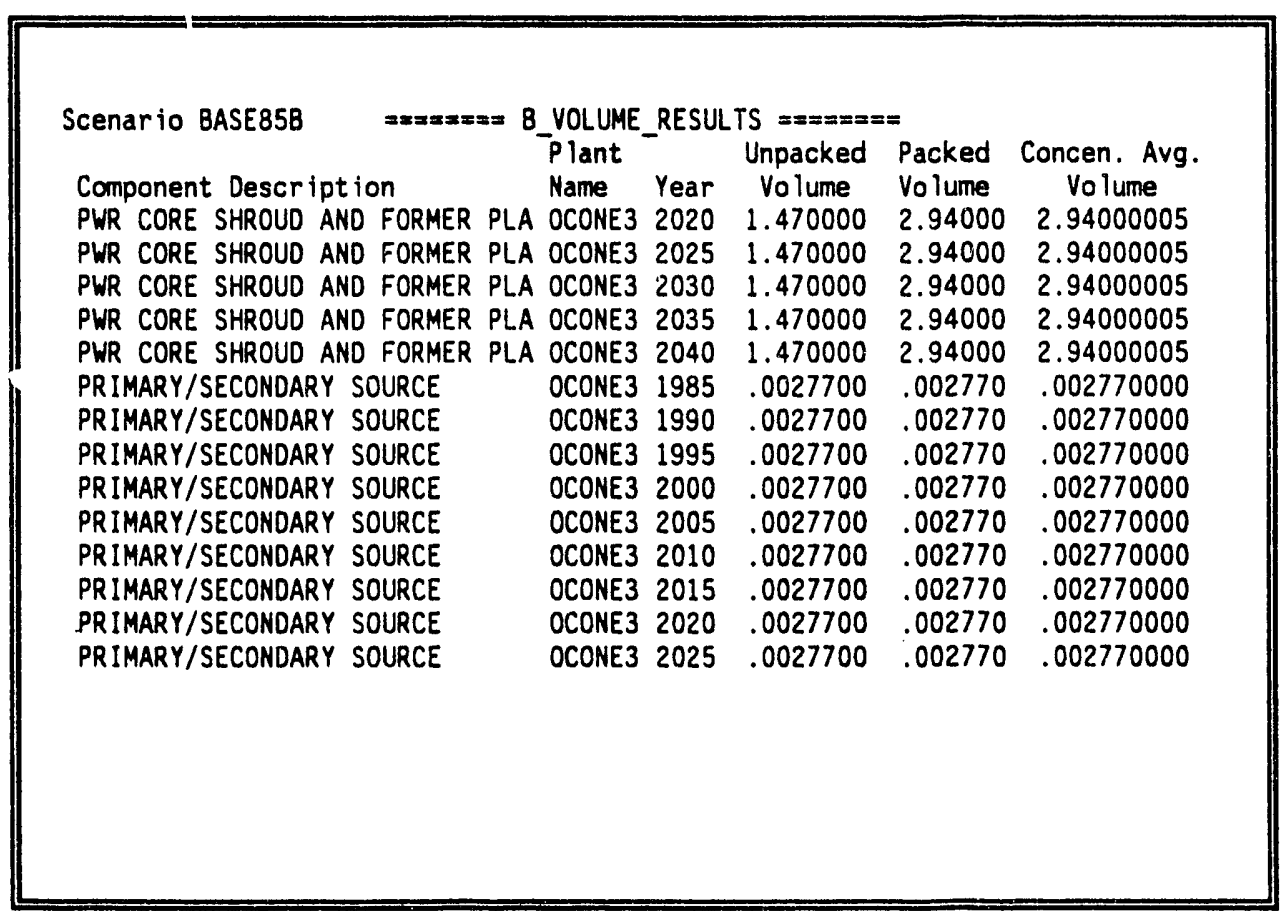

Figure 26. Query projections to screen.

2. Use the up and down arrow keys to move to a desired data set, and press Commit to view projected activities. The following screen will appear (Figure 27).

Press Exit to quit this option and return to the main menu. 
NOTE: These query activities may take a few minutes, as many records are searched for the results.

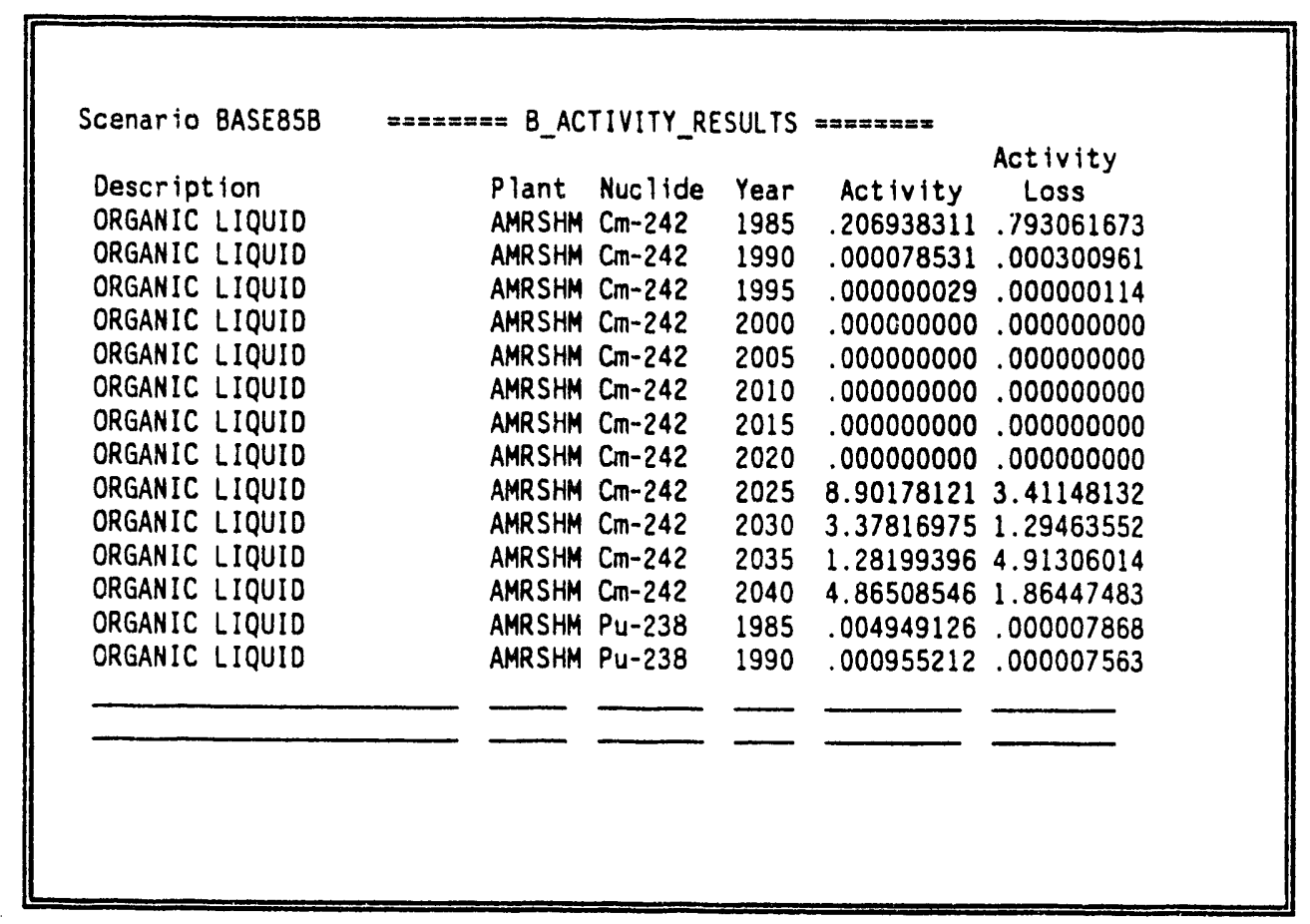

Figure 27. Volume results screen.

3. Press Exit to return to the main menu. 


\section{Delete Scenario}

1. From the main menu, type 6 and press $<$ ENTER>. The following screen should appear (Figure 28).

To select a scenario, see Section 5, page 17.

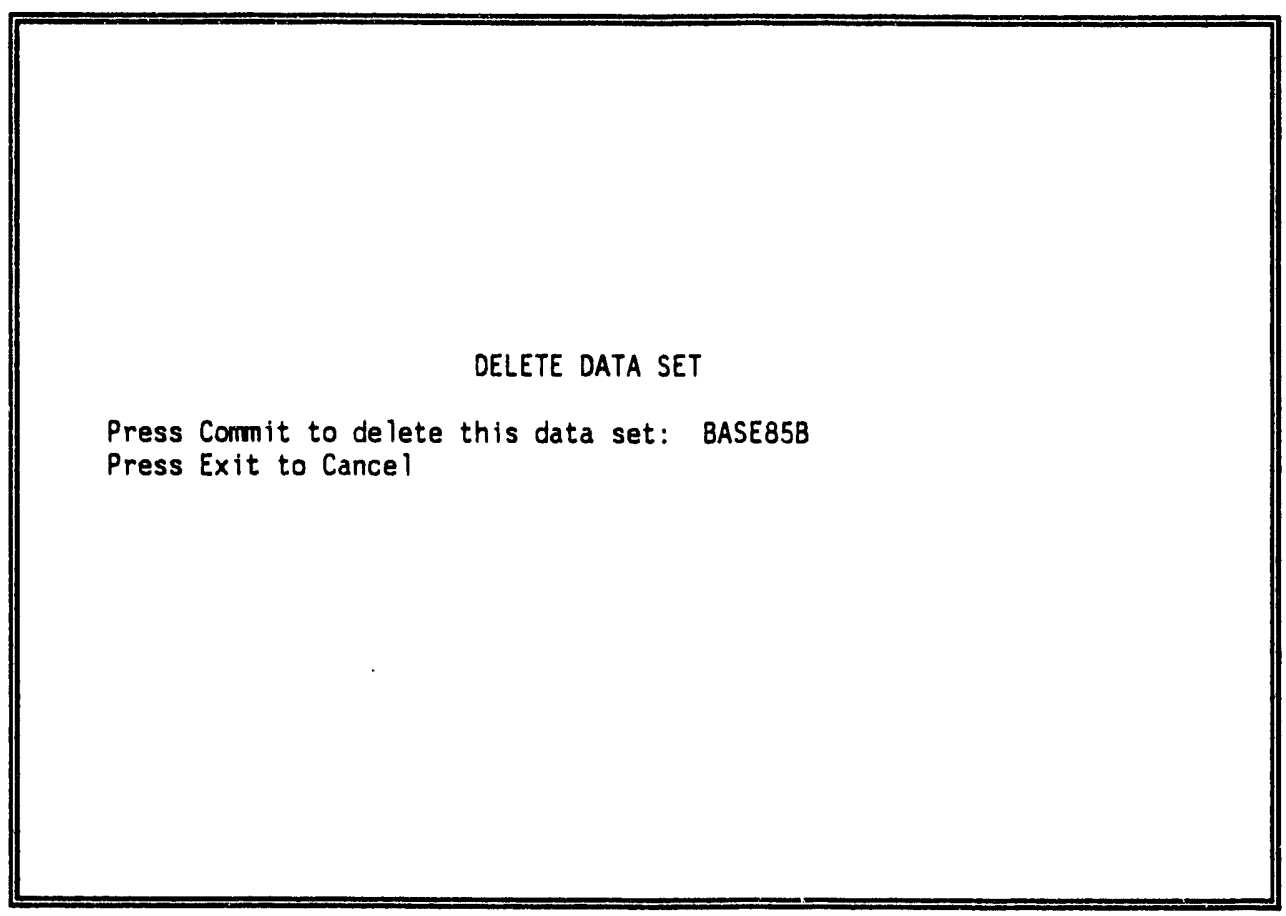

Figure 28. Delete scenario screen.

2. Press Commit to delete the data set. NOTE: Upon pressing Commit, all data associated with the selected data set will be destroyed! Please review the data set name and the delete decision carefully before pressing Commit. 
Press Exit to cancel the delete option and return to the main menu. 


\section{Master User Edit}

Only system administrators have access to this option. Should data contained in the master edit tables need to be modified, please submit notification via internal company memo to the GTCC LLW Program Manager and/or the GTCC LLW Data Base Administrator. 
Section 11

Master User Edit

60 


\section{Appendix}




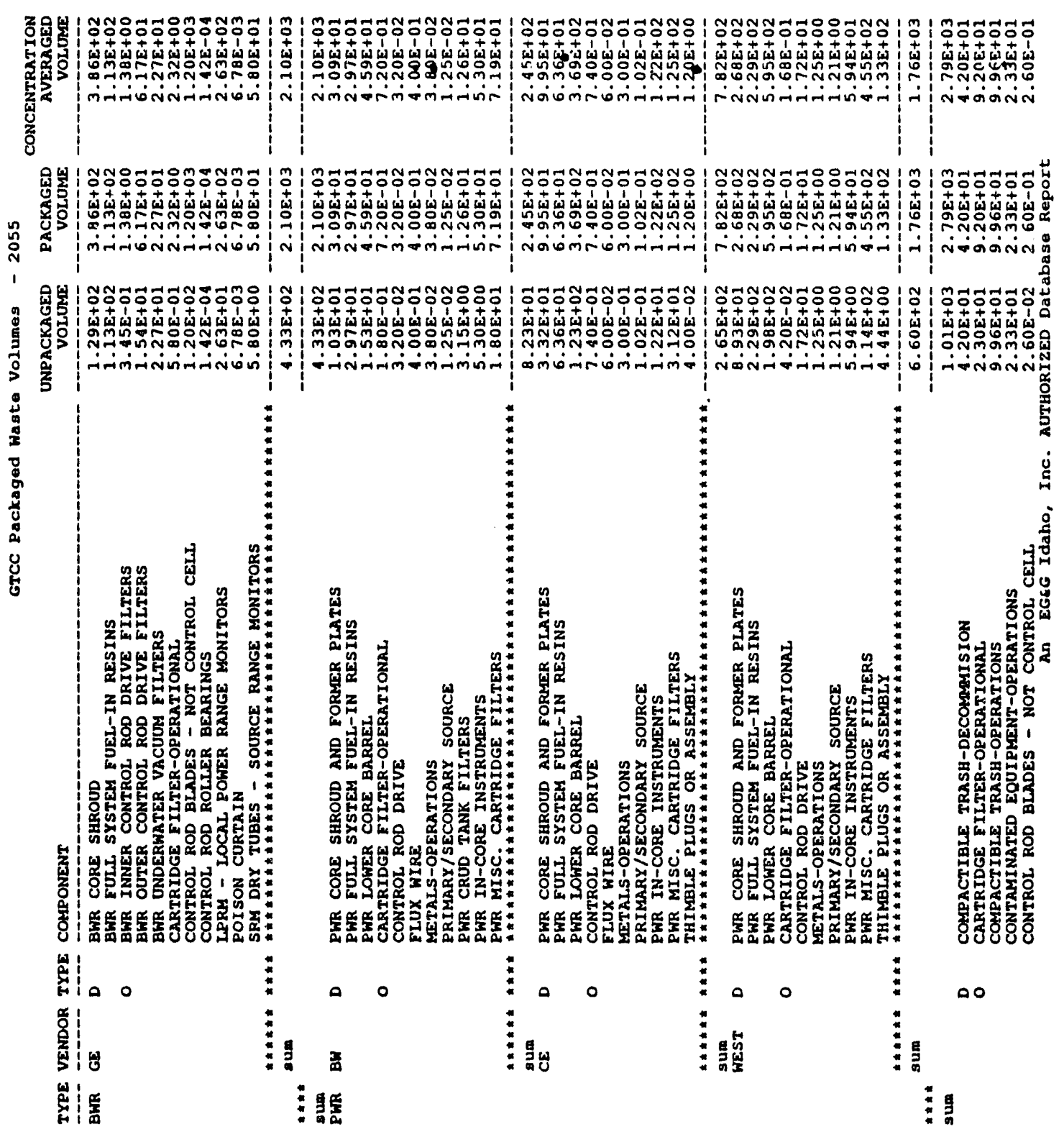




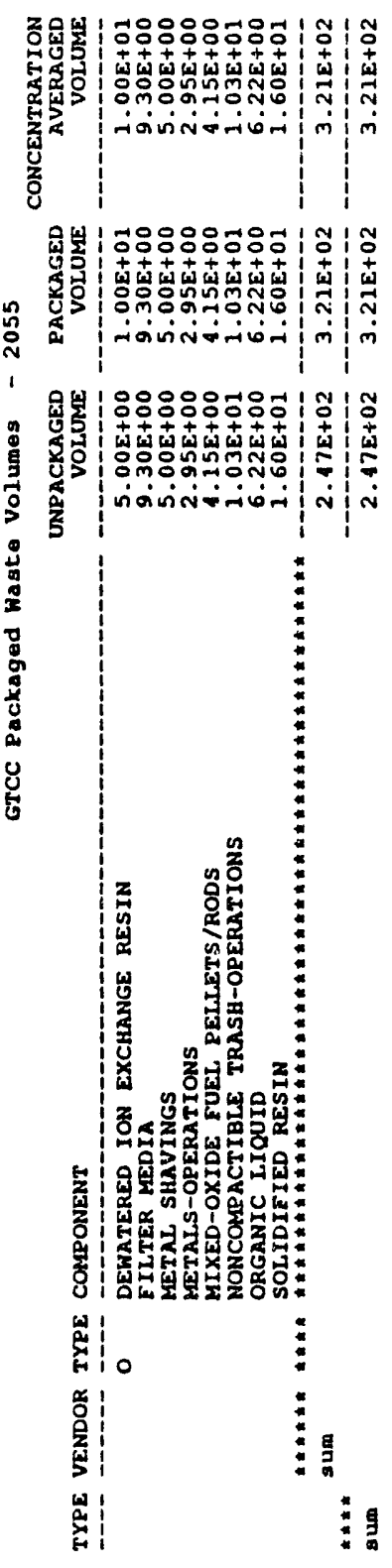




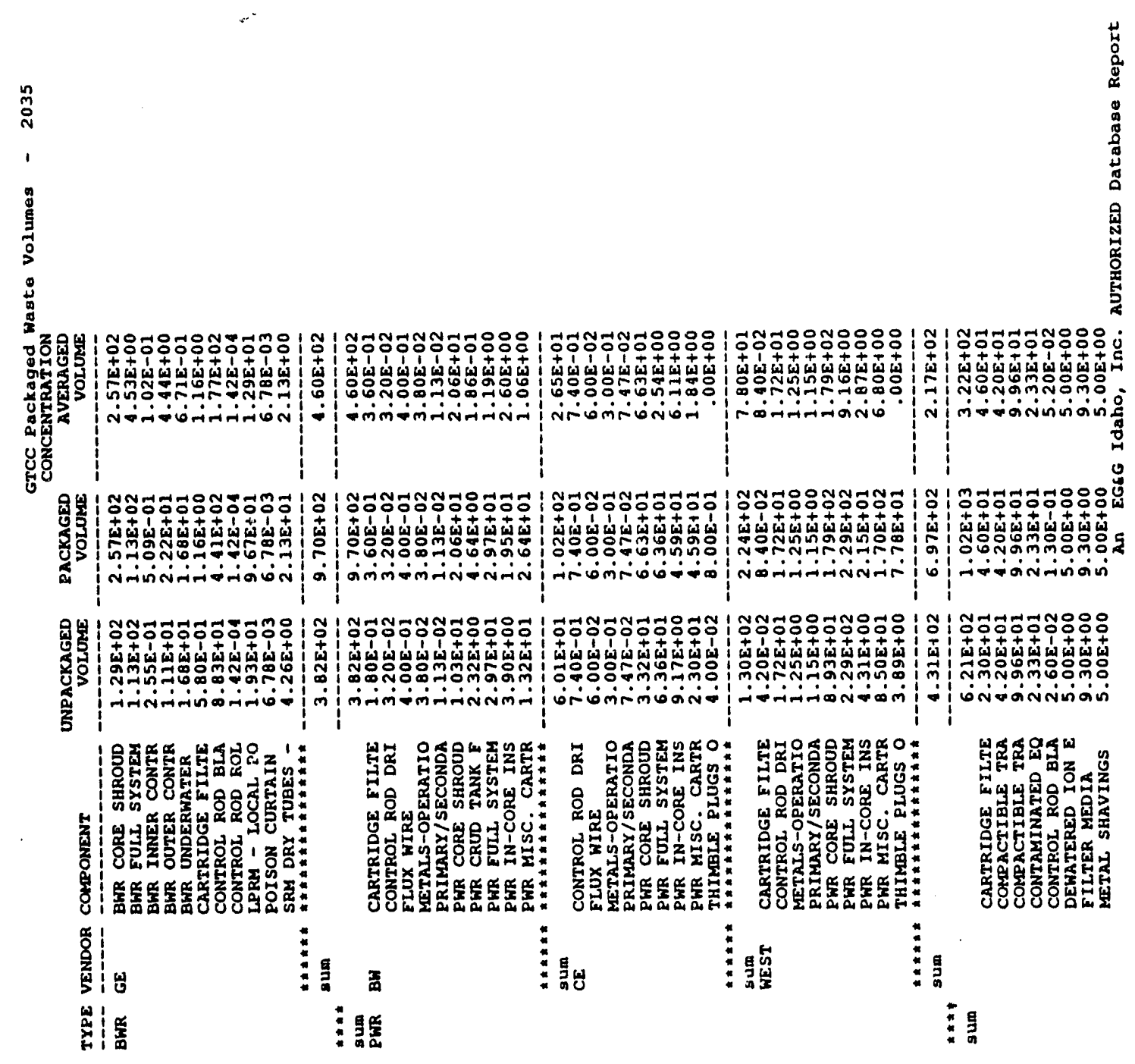




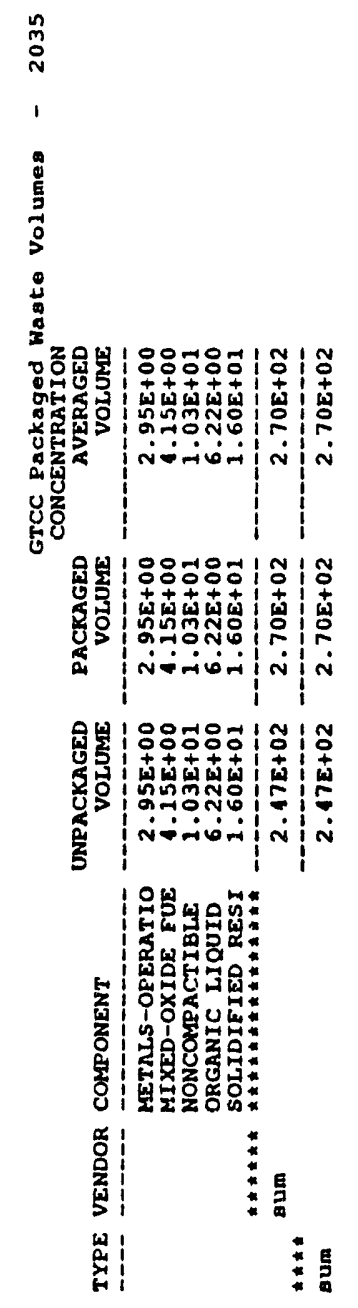

66 


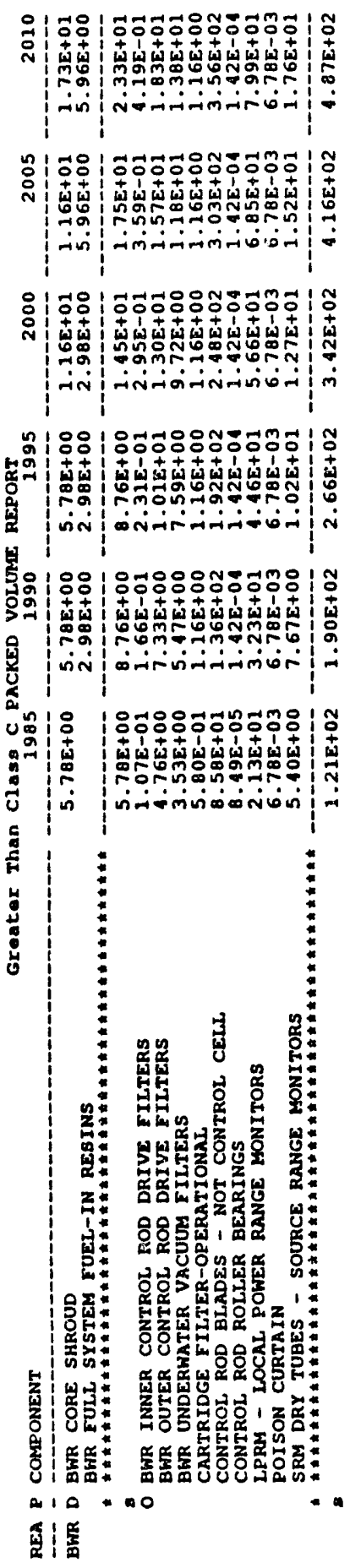

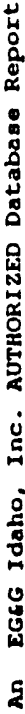






ग्ञ

68 


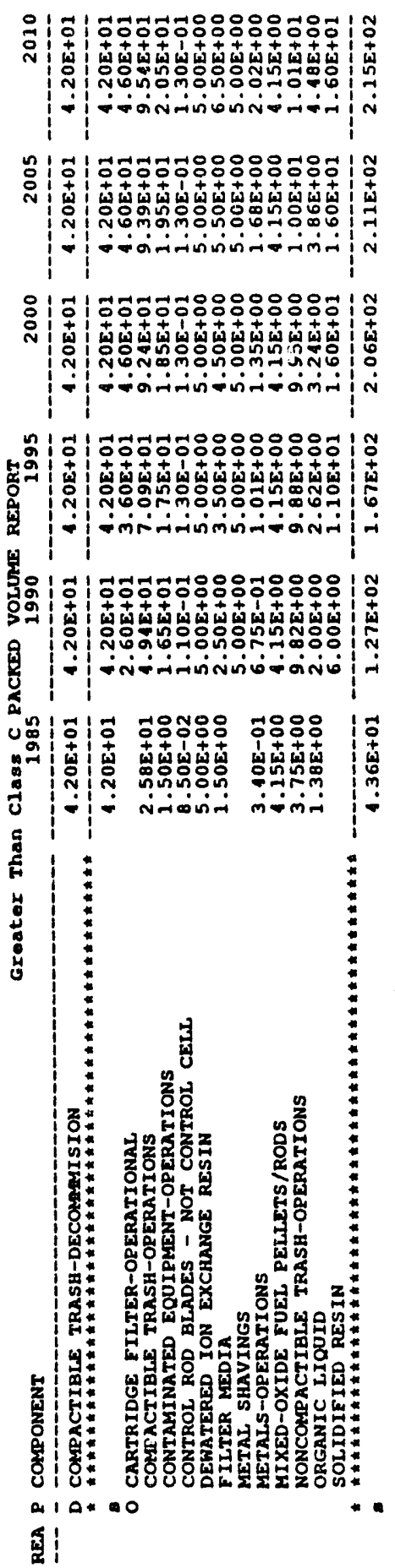




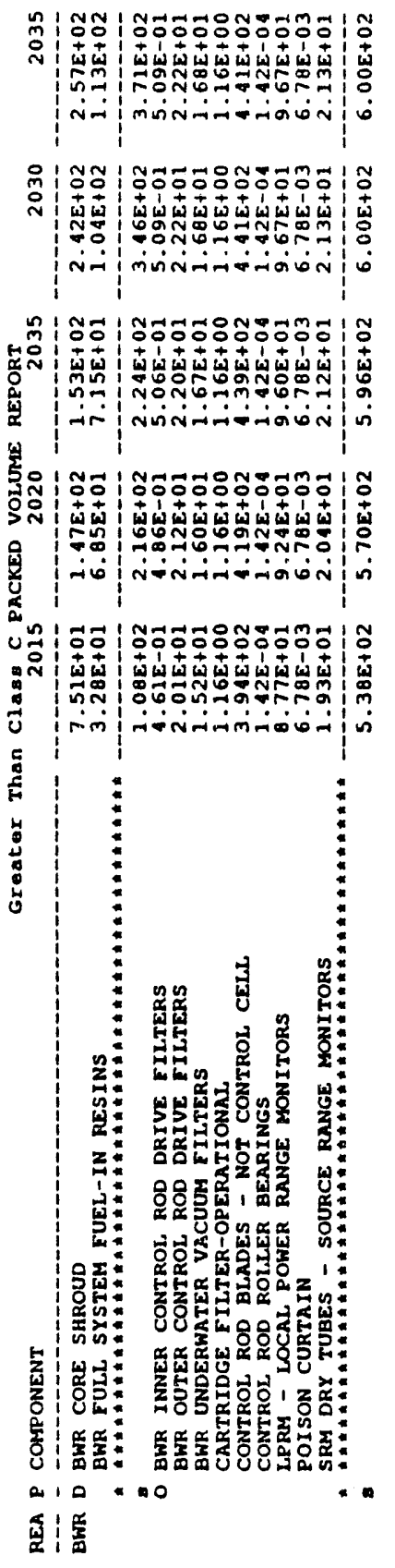



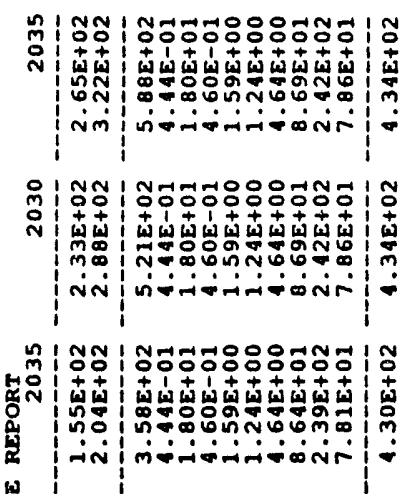



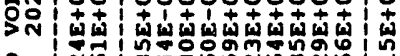
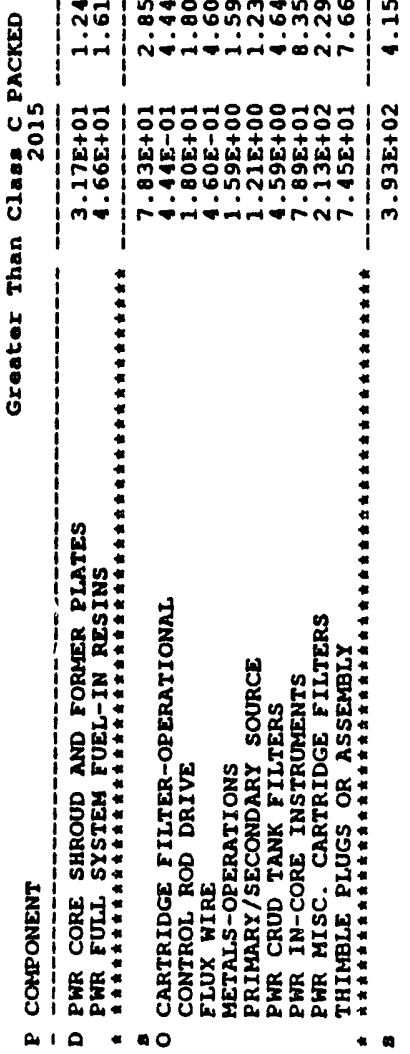

鼻㵙 


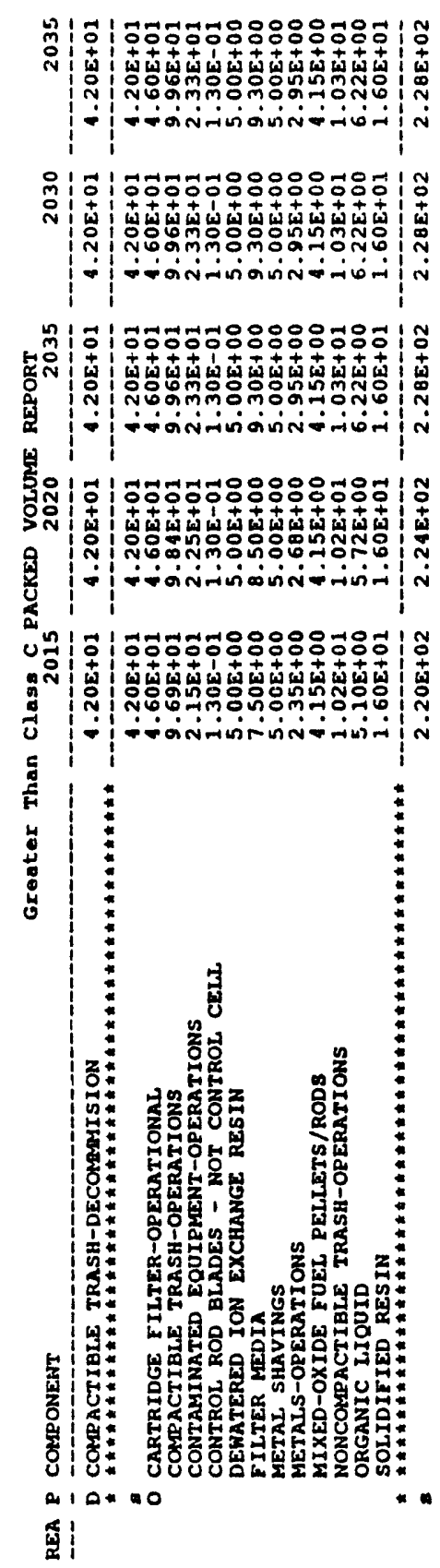



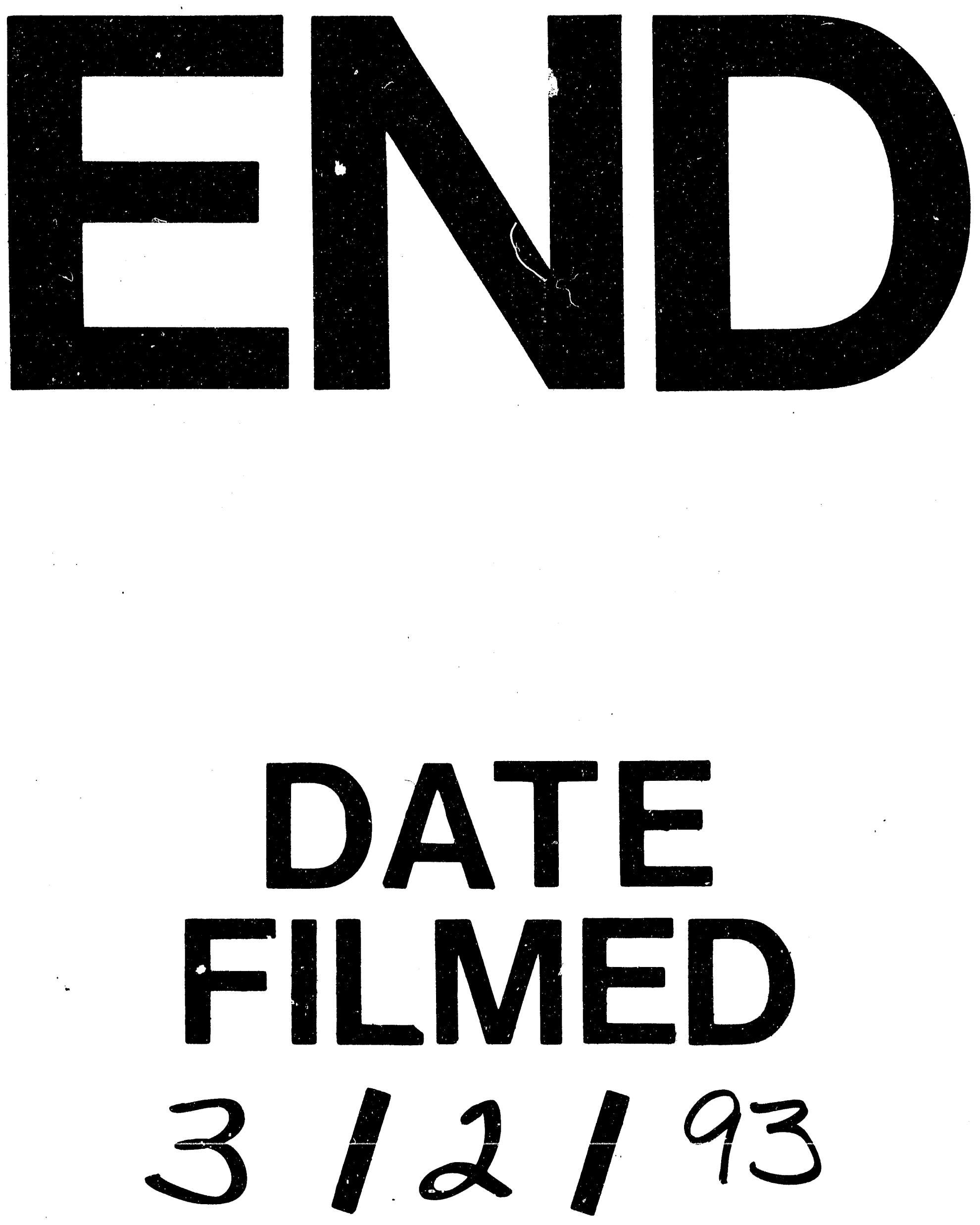
$n$ 